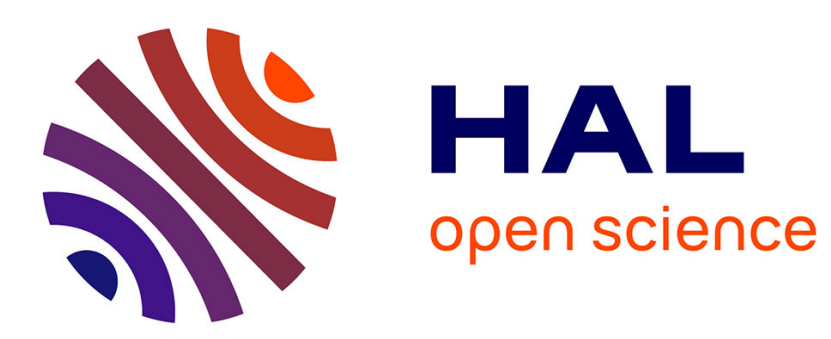

\title{
Asymmetric Synthesis of New $\beta$-Lactam Lipopeptides as Bacterial Signal Peptidase I Inhibitors
}

Céline Crauste, Matheus Froeyen, Jozef Anné, Piet Herdewijn

\section{To cite this version:}

Céline Crauste, Matheus Froeyen, Jozef Anné, Piet Herdewijn. Asymmetric Synthesis of New $\beta$ Lactam Lipopeptides as Bacterial Signal Peptidase I Inhibitors. European Journal of Organic Chemistry, 2011, 2011 (19), pp.3437-3449. 10.1002/ejoc.201100148 . hal-02309796

\section{HAL Id: hal-02309796 \\ https://hal.science/hal-02309796}

Submitted on 9 Oct 2019

HAL is a multi-disciplinary open access archive for the deposit and dissemination of scientific research documents, whether they are published or not. The documents may come from teaching and research institutions in France or abroad, or from public or private research centers.
L'archive ouverte pluridisciplinaire HAL, est destinée au dépôt et à la diffusion de documents scientifiques de niveau recherche, publiés ou non, émanant des établissements d'enseignement et de recherche français ou étrangers, des laboratoires publics ou privés. 
archives-ouvertes

\section{Asymmetric Synthesis of New $\beta$-Lactam Lipopeptides as Bacterial Signal Peptidase I Inhibitors}

Céline Crauste, Matheus Froeyen, Jozef Anné, Piet Herdewijn

\section{To cite this version:}

Céline Crauste, Matheus Froeyen, Jozef Anné, Piet Herdewijn. Asymmetric Synthesis of New $\beta$ Lactam Lipopeptides as Bacterial Signal Peptidase I Inhibitors. EUROPEAN JOURNAL OF ORGANIC CHEMISTRY, 2011, 2011 (19), pp.3437-3449. 10.1002/ejoc.201100148 . hal-02309796

\section{HAL Id: hal-02309796 \\ https://hal.archives-ouvertes.fr/hal-02309796}

Submitted on 9 Oct 2019

HAL is a multi-disciplinary open access archive for the deposit and dissemination of scientific research documents, whether they are published or not. The documents may come from teaching and research institutions in France or abroad, or from public or private research centers.
L'archive ouverte pluridisciplinaire HAL, est destinée au dépôt et à la diffusion de documents scientifiques de niveau recherche, publiés ou non, émanant des établissements d'enseignement et de recherche français ou étrangers, des laboratoires publics ou privés. 


\title{
Asymmetric Synthesis of New $\beta$-Lactam Lipopeptides as Bacterial Signal Peptidase I Inhibitors
}

\author{
Céline Crauste, ${ }^{[a]}$ Matheus Froeyen, ${ }^{[a]}$ Jozef Anné, ${ }^{[b]}$ and Piet Herdewijn ${ }^{*[a]}$
}

Keywords: Medicinal chemistry / Antibiotics / Enzymes / Peptides / Lactams / Asymmetric synthesis

The transmembrane bacterial enzyme, signal peptidase I, is recognized as being a promising target for reducing the emergence of drug resistance. The asymmetric synthesis and the biological evaluation of original $\beta$-lactam lipopeptides have been performed to discover potent signal peptidase in- hibitors. The importance of the azetidinone motif of these lipopeptides has been demonstrated and can serve as a starting point to exploit and improve the reactivity of the $\beta$-lactam in peptidomimetics.

\section{Introduction}

Faced with the emergence of drug-resistant bacteria, the discovery of antibiotics that act by novel and various mechanisms is of crucial importance. The bacterial enzyme, signal peptidase I (SPase I), has received increasing interest as a potential new target for the discovery of antibacterial agents. ${ }^{[1]}$ This transmenbrane enzyme appears to be essential for the viability of both Gram-positive and -negative bacteria (i.e., Escherichia coli and Staphylococcus aureus)..$^{[2,3]}$ Its physiological function is to ensure the release of secreted bacterial proteins by cleaving off the signal peptide from translocated pre-proteins. The bacterial signal peptidases use a unique dyad mechanism that involves serine and lysine amino acids, whereas eukaryotic signal peptidases use a different dyad mechanism based on serine and histidine amino acids. ${ }^{[4]}$ As a consequence, it should be possible to develop specific SPase I inhibitors with high selectivity and low toxicity.

The natural substrates of SPase I contain a $C$-terminal domain (c-region) that is responsible for substrate recognition. In most cases alanines are found in proximity to the cleavage site in the $\mathrm{P} 1$ and $\mathrm{P} 3$ positions. ${ }^{[5,6]}$ Therefore the substrate recognition rule is often called the Ala-X-Ala (AXA) rule. This observation was confirmed by the crystal structure of E. coli SPase I LepB, with two small hydrophobic pockets (S1 and S3) identified on the surface of the

[a] Laboratory for Medicinal Chemistry, Rega Institute for Medical Research, Katholieke Universiteit Leuven, Minderbroedersstraat 10, 3000 Leuven, Belgium Fax: +32-16-337340 E-mail: Piet.Herdewijn@rega.kuleuven.be

[b] Department of Microbiology and Immunology, Rega Institute for Medical Research, Katholieke Universiteit Leuven, Minderbroedersstraat 10, 3000 Leuven, Belgium E-mail: Jozef.anne@rega.kuleuven.be

$\square$ Supporting information for this article is available on the WWW under http://dx.doi.org/10.1002/ejoc.200900148. catalytic domain of the enzyme in which both alanine residues (AXA) of natural peptide substrates are oriented. ${ }^{[7]}$

Various classes of molecules have been described as potential inhibitors of SPase I of E. coli: $\beta$-Lactam compounds such as the allyl $(5 S, 6 S)-6-[(R)$-acetoxyethyl]penem3-carboxylate (Penem A, see part A of Figure 1 and Figure 2), ${ }^{[8,9]}$ peptides (Arylomycin A2), ${ }^{[10]}$ and lipoglycopeptide derivatives. ${ }^{[11]}$ For peptide derivatives, $N$-terminal acylation with fatty acids like decanoyl acid seem to enhance the potency of the inhibitors. ${ }^{[12,13]}$ The decanoyl chain is believed to interact with the membrane or the detergent used for modeling the membrane bilayer in in vitro assays. ${ }^{[7]}$

Up to now, small peptides that mimic the protein cleavage site have proven to be inefficient as SPase I inhibitors. ${ }^{[14]}$ However, we first investigated the possibility of developing small peptidomimetics as potential SPase I inhibitors based on the presence of the $N$-decanoyl side-chain and the AXA moiety. Our work ${ }^{[13]}$ led to the discovery of a decanoyl-PTANA-COH peptide aldehyde (Figure 2) with an $\mathrm{IC}_{50}$ value of $0.09 \mu \mathrm{M}$ when tested against $\mathrm{SPsB}$, the SPase I of $S$. aureus. This lipopeptide inhibitor has a $C$ terminal aldehyde function that allows nucleophilic attack of the serine amino acid involved in the peptide cleavage mechanism. ${ }^{[15,16]}$ Despite its "serine trap" efficiency, the aldehyde function is often metabolically unstable and hence its replacement by other classes of electrophiles would be a promising optimization. Several chemically reactive groups have been introduced into protease inhibitor structures to act as "serine traps", like trifluoromethyl ketones, ${ }^{[17]} \alpha$-keto amides, ${ }^{[18]} \beta$-lactams, ${ }^{[19,20]}$ or boronic acids. ${ }^{[21,22]}$ Among them, the $\beta$-lactam residue is the only one previously described in non-peptidic SPase I inhibitors. ${ }^{[8,9]}$ Therefore, to improve the activity of the decanoyl-PTANA-COH lipopeptide and to obtain more information on the binding of this kind of inhibitor in the active site of the enzyme, we replaced the aldehyde function by $\beta$-lactam residues, commonly used in other protease inhibitors ${ }^{[20,23,24]}$ (compounds 

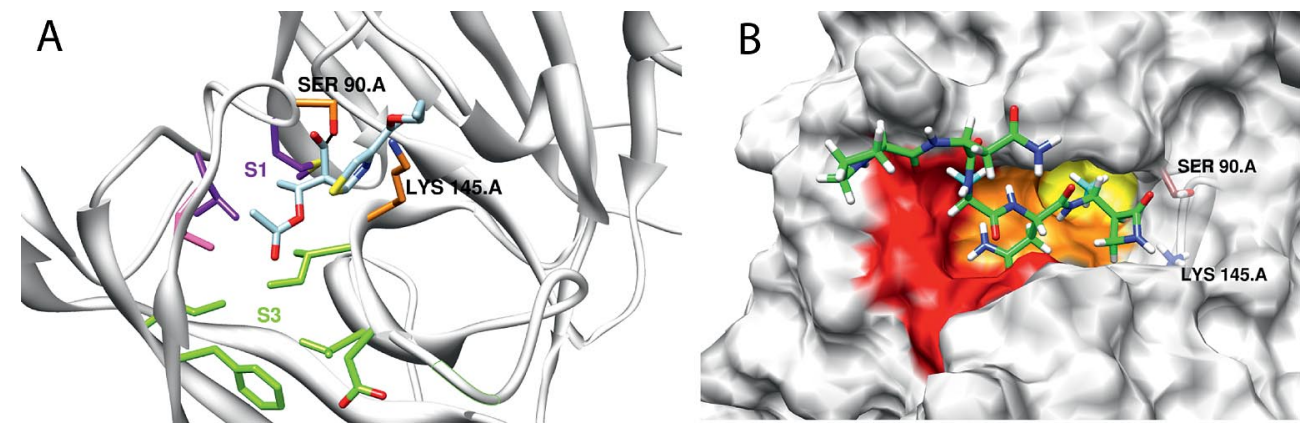

Figure 1. A: Structure of Penem A in E. coli SPase I covalently bound to Ser90. ${ }^{[7]}$ B: Model of decanoyl-PTAN-aminoethyl-azetidinone 1a (without decanoyl) in the E. coli SPase I active site. The S1 site is printed in yellow, the S3 site in red, and common residues in orange. The Ser90 and Lys145 active site residues are also shown (C atoms: grey). The two alanine side-chains in the AXA motif are printed in cyan.

\section{Described Spase $\underline{\text { Inhibitors }}$}

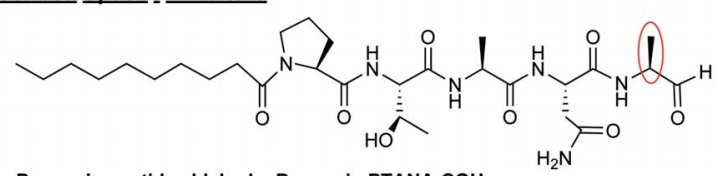

Decanoic peptide aldehyde: Decanoic-PTANA-COH

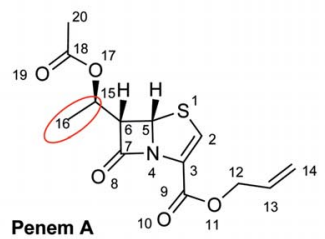

New $\beta$-lactam lipopeptide Spase I inhibitors
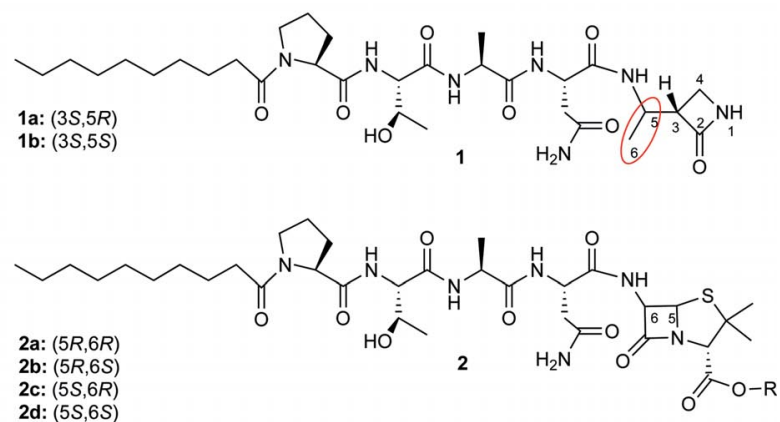

Synthetic precursors

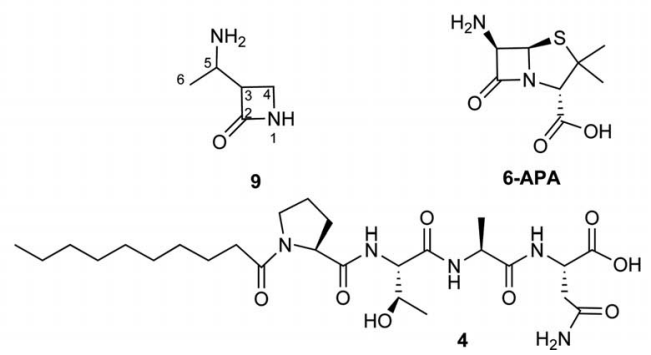

Figure 2. Chemical structures of previously described SPase I inhibitors (decanoic-peptide-aldehyde ${ }^{[13]}$ and Penem $\mathbf{A}^{[8,9]}$ ), potential new lipopeptide inhibitors ( $\mathbf{1}$ and $\mathbf{2}$ ), and their synthetic precursors.

1 and 2). Because an appropriate stereochemistry of the $\beta$ lactam structure is essential for its biological activity, ${ }^{[8,25]}$ we focused our work on the synthesis of several isomers of this new class of $\beta$-lactam lipopeptides. We report herein the design, synthesis, and biological evaluation of these new $\beta$-lactam-lipopeptides.

\section{Results and Discussion}

The research started with modeling experiments by docking potential peptidomimetics in the catalytic site of the enzyme and selecting the best-fitting molecules for future synthesis. The model of the new lipopeptides was created starting from the X-ray structure of the E. coli Signal peptidase I acyl-enzyme ${ }^{[7]}$ covalently bound to the $5 S, 6 S \beta$-lactam inhibitor Penem A (Figure 2). This crystal structure (Figure 1, A) shows that the binding to $E$. coli SPase I can be influenced by the properties of the C6 substituent of such penems oriented towards the $\mathrm{S} 1$ hydrophobic pocket, whereas modification at the $\mathrm{C} 2$ and $\mathrm{C} 3$ positions offers little or no opportunity for binding optimization. ${ }^{[26]}$ In fact, cocrystallization reveals that the 16-methyl group of Penem A is oriented toward the S1 pocket of the active site of the enzyme (like the alanine residue in the $\mathrm{P} 1$ position of natural substrates). However, no access to the S3 pocket is revealed with this penem inhibitor.

As the modeling experiments ${ }^{[7]}$ predicted that the methyl moiety of a $\beta$-lactam alkyl ester residue could mimic the last amino acid of the AXA sequence oriented towards the $\mathrm{S} 1$ pocket, we investigated the design of a new class of peptide inhibitors to optimize the orientation towards both the $\mathrm{S} 1$ and S3 pockets. We planned to combine the structures and properties of the decanoyl-peptide and a $\beta$-lactam residue. Therefore we decided to replace the last alanine residue of the decanoyl-PTANA-COH peptide by the aminoethylazetidinone 9 (Figure 2) to create lipopeptide of type 1 with a monocyclic $\beta$-lactam moiety. We initially chose a monocyclic $\beta$-lactam (mono-bactam) residue because no interactions were observed between the enzyme and the five-membered ring of Penem A. ${ }^{[26]}$ By introducing the decanoylPTAN moiety onto the amino group of the azetidinone $\mathbf{9}$, we expected to optimize the interactions with the S3 pocket to increase the affinity for the active site. 
To choose the appropriate stereochemistry for the synthesis of the lipopeptide $\mathbf{1}$, we first focused on the results published by Allsop et al. ${ }^{[8]}$ According to them, the $15 R$ configuration of Penem A seems to be essential for activity. Indeed by modeling both lipopeptides $\mathbf{1 a}$ and $\mathbf{1 b}$ inside the $E$. coli SPase I active site, a better fit was observed for the $5 R$ lipopeptide 1a (Figure 1, B). ${ }^{[27]}$ In this theoretical model, the two methyl functions (the methyl group of alanine and the 6-methyl group) colored in cyan appear to fit into both hydrophobic pockets S1 and S3. However, the C5 carbon of the lipopeptide 1a, which mimics the $\alpha$ carbon of the alanine residue, has an $R$ configuration (D), in contrast to the natural $S$ configuration (L) seen for all natural amino acids. Because of this observation both the $5 R$ and $5 S$ isomers of molecule 1 were synthesized and evaluated.

Based on the structures of the two SPase I inhibitors described (Figure 2), we also explored the direct coupling of the decanoic peptide with the commercially available and inexpensive 6-aminopenicillanic acid (6-APA, compounds 2a-d). In this case, substrate recognition was based only on the decanoyl-PTAN moiety and the "serine trap" reactivity was introduced through a bicyclic penam moiety. The biological activity of the Penem A has been described only for its $c i s-5 S, 6 S$ isomer, which has the opposite stereochemistry to most $\beta$-lactam antibiotics, and the starting material 6APA. Thus, synthetic schemes had to be elaborated to invert both stereocenters of the 6-APA to obtain the four diastereoisomers of compound $\mathbf{2}$ and explore the importance of the stereochemistry for the activity of this new class of potential SPase I inhibitors. Indeed, synthetic schemes to invert the configuration and obtain the amine-free penam of the 6-APA derivative are poorly described due to the instability of the unprotected penam $\beta$-lactam ring.

The synthesis of the lipopeptides $\mathbf{1}$ and $\mathbf{2}$ first required the solid-phase synthesis of decanoyl-PTAN-COOH peptide $\mathbf{4}$, which was then coupled to the appropriate residues 9 or 14. The supported synthesis was performed on a Wang resin using classical coupling reagents (HOBt/DIPEA/DIC) for peptide bond formation and Fmoc-protected amino acids. ${ }^{[28]}$ The last steps involved $N$-terminal decanoylation followed by side-chain deprotection and cleavage from the solid support using a TFA/ $\mathrm{H}_{2} \mathrm{O} /$ thioanisole solution.

The azetidinone-peptides 1a,b were synthesized by condensation between decanoyl-PTAN-COOH and the $(5 R)$ or (5S)-(1-aminoethyl)azetidinone $\mathbf{9 a}$ or $\mathbf{9 b}$ (for atom numbering see Scheme 1). We used the commercially available silylated azetidinone as the starting material to give the (5R)-hydroxyazetidinone 6a (Scheme 1). Reduction of the commercially protected $\beta$-lactam with $\mathrm{NaBH}_{4}$ in ethanol at $10{ }^{\circ} \mathrm{C}^{[29]}$ led to the C4-unsubstituted compound $\mathbf{5}$ in $81 \%$ yield. Deprotection of the silyl group was performed by using $\mathrm{HCl}$ solution ${ }^{[30]}$ to afford $\mathbf{6 a}$ in $77 \%$ yield whereas TBAF deprotection ${ }^{[31]}$ gave only $40 \%$ yield due to some degradation. The hydroxyazetidinone $\mathbf{6 a}$ obtained was then used as the starting material to synthesize both the $(5 R)$ and $(5 S)$-aminoazetidinones $\mathbf{9 a}$ and $\mathbf{9 b}$.

The (5S)-(1-aminoethyl)azetidinone 9a was synthesized following a sequence of mesylation, aziridination, and re-

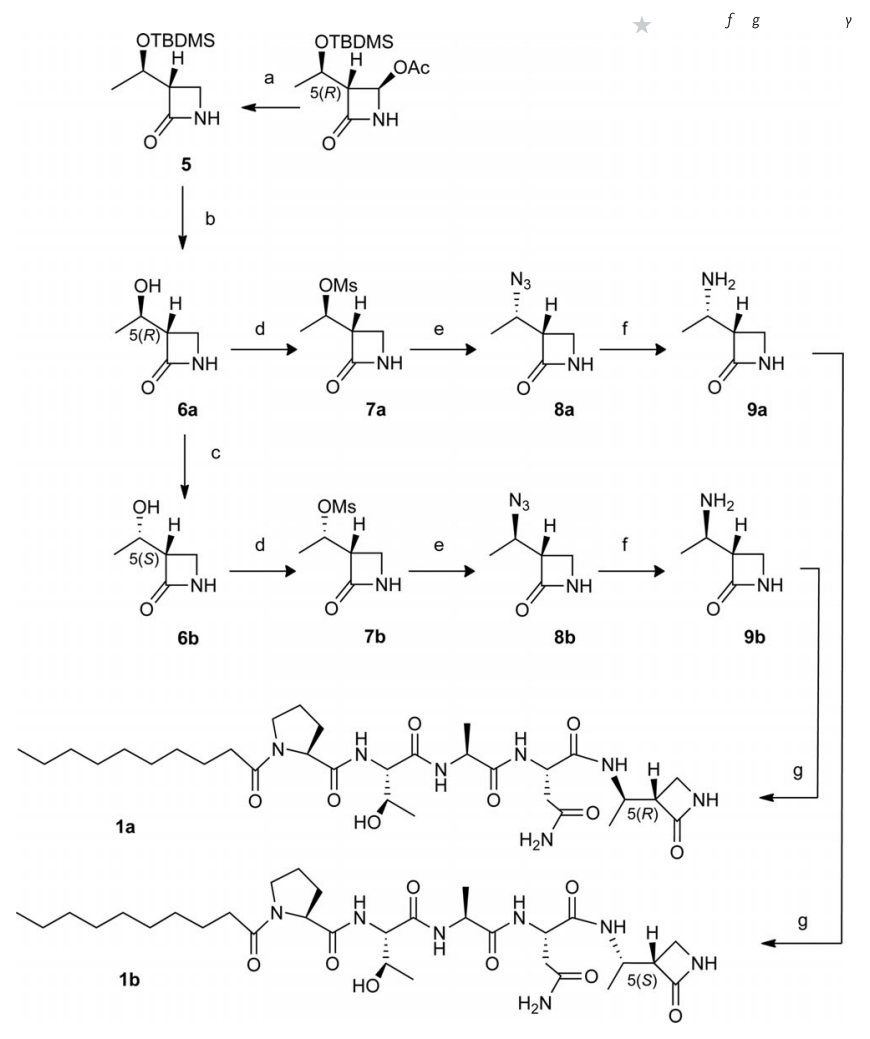

Scheme 1. Reagents and conditions: (a) $\mathrm{NaBH}_{4}, \mathrm{EtOH}_{\text {abs }}, 10^{\circ} \mathrm{C}$, $1 \mathrm{~h} 30 \mathrm{~min}\left(81 \%\right.$ ); (b) $1 \mathrm{~N} \mathrm{HCl}, \mathrm{CH}_{3} \mathrm{CN}$, room temp., $1 \mathrm{~h} 30 \mathrm{~min}$ (77\%); (c) i. $\mathrm{PhCOOH}, \mathrm{PBu}_{3}, \mathrm{TMAD}, 60{ }^{\circ} \mathrm{C}, 1 \mathrm{~d}$, $(35 \%)$; ii. $5 \mathrm{M}$ $\mathrm{NaOH}, \mathrm{MeOH}$, room temp., overnight (70\%); (d) $\mathrm{MsCl}$, pyridine, $0{ }^{\circ} \mathrm{C}$, 2 h 30 min (7a: 99\%; 7b: 60\%); (e) $\mathrm{LiN}_{3}$, DMF, $60{ }^{\circ} \mathrm{C}$, overnight (8a: $81 \%$; 8b: $80 \%$ ); (f) $\mathrm{H}_{2} 10 \% \mathrm{Pd} / \mathrm{C}, \mathrm{MeOH}$, room temp., 3 h (9a: 80\%; 9b: 84\%); (g) Dec-PTAN-COOH (4), HOBt, DIPEA, EDCI, DMF/DCM, room temp., 6 h (1a: 62\%; 1b: 45\%).

duction processes. Unexpectedly, the trivial conversion of the hydroxy function into an activated mesylate 7a presented some difficulties. ${ }^{[32]}$ Of the solvents tested (DMF, DCM, and pyridine), only pyridine was found to be appropriate and several additions of $\mathrm{MsCl}$ during the reaction were needed to achieve completion of the reaction. Nucleophilic displacement of the mesylate $7 \mathbf{a}$ with lithium azide was performed at $60{ }^{\circ} \mathrm{C}$ to provide the $(5 S)$-azidoazetidinone $\mathbf{8 a}$ ( $81 \%$ yield), which, after hydrogenolysis, afforded the desired aminoazetidinone $\mathbf{9 a}$.

To obtain the $5 R$ isomer $9 \mathbf{b}$ from the hydroxyazetidinone 6a, an inversion of the absolute configuration at the $\mathrm{C} 5$ position was performed by Mitsunobu esterification followed by saponification. ${ }^{[33,34]}$ Under the usual Mitsunobu conditions of DEAD (diethyl azodicarboxylate), $\mathrm{PPh}_{3}$ (triphenylphosphane), and benzoic acid, the reaction was low yielding and most of the starting material was recovered. Several reaction methods were investigated in an attempt to improve its efficiency. ${ }^{[35]}$ As this reaction is known to be highly sensitive to the steric hindrance of the starting alcohol, several methods were developed to overcome this drawback. We tried to perform the nucleophilic substitution by replacing benzoic acid by a stronger acid (nitrobenzoic acid). However, additional degradation reactions and the formation of side-products were observed. The activation 
of the hydroxy function was then tested by using a mixture of DIAD (diisopropyl azodicarboxylate)/ $\mathrm{PPh}_{3}, \mathrm{ADDP}$ (azodicarbonyldipiperidine)/ $\mathrm{PBu}_{3}$ (tributylphosphane), ${ }^{[36]}$ or TMAD ( $N, N, N^{\prime}, N^{\prime}$-tetramethylazodicarboxamide $) /$ $\mathrm{PBu}_{3} \cdot{ }^{\left[{ }^{[3]}\right.}$ The use of ADDP or TMAD as activating reagent coupled with the more nucleophilic phosphane $\mathrm{PBu}_{3}$ increased the yield up to $35 \%$. These conditions also facilitated the purification step. (5S)-Hydroxyazetidinone $\mathbf{6 b}$ was then obtained after saponification. Finally, the desired $(5 R)$-aminoazetidinone $\mathbf{9 b}$ was obtained from the hydroxy derivative $\mathbf{6 b}$ after mesylation, aziridination, and reduction processes, as described above.

Both (5R)- and (5S)-aminoazetidinones 9 were then coupled to the previously synthesized decanoyl-PTAN-COOH (4) by using the usual coupling reagents (HOBt/EDCI). The $5 S$ isomer of the lipopeptide $\mathbf{1}$ was obtained in diastereomerically pure form. However, after purification by chromatography and semi-preparative reversed-phase HPLC, ${ }^{1} \mathrm{H}$ NMR analysis of the $5 R$ isomer 1a showed a small proportion of a second product, probably formed by epimerization at the $\mathrm{C} 3$ position.

In the second part of our work, we focused on the synthesis of lipopeptides 2a-d, directly conjugated to penam residues. This synthetic pathway started with the synthesis of the four 5,6 diastereoisomers of the commercially available 6-APA (14a-d; Scheme 2). Epimerization at the 6- and/ or 5-positions has already been reported for penicillin bearing an imido substituent at the 6-position and ester protection of the carboxylic function. ${ }^{[38-41]}$ Indeed, it has been recognized that phthalimido-substituted $\beta$-lactam is more stable to a wide variety of reaction conditions than the corresponding amido derivatives. Moreover, the synthetic yield of the cis-5S,6S isomer $\mathbf{1 4 d}$, starting from the $(5 R, 6 R)-6$ -

\section{Epimerization steps}

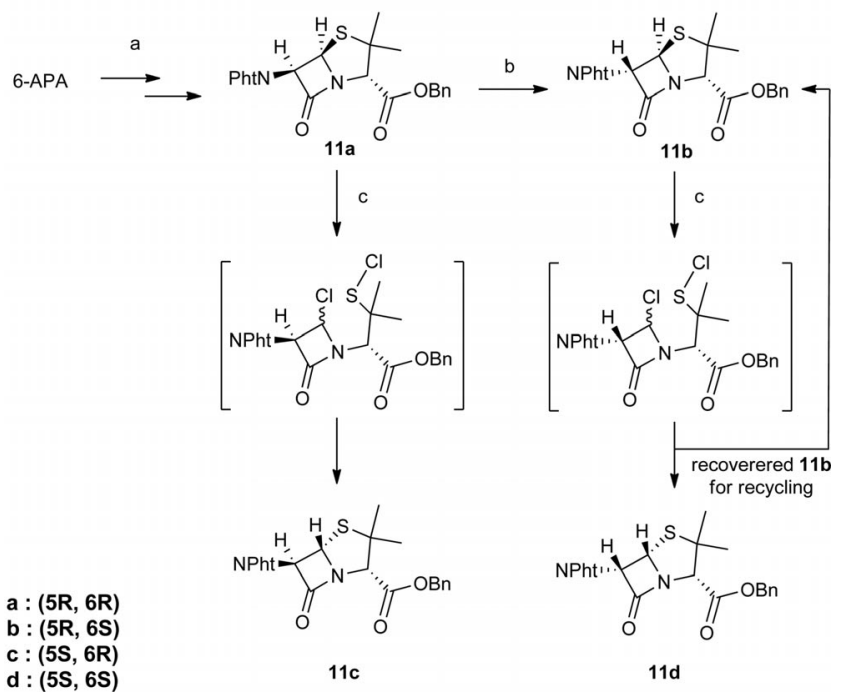

Scheme 2. Reagents and conditions: (a) i. $N$-(ethoxycarbonyl)phthalimide, $\mathrm{Na}_{2} \mathrm{CO}_{3}, \mathrm{H}_{2} \mathrm{O}$, room temp., $3 \mathrm{~h}$ (70\%); ii) $\mathrm{BnBr}_{3} \mathrm{NEt}_{3}$, DMF, room temp., $6 \mathrm{~h} \mathrm{(61 \% );} \mathrm{(b)} \mathrm{DBU,} \mathrm{DCM,} \mathrm{room} \mathrm{temp.,} 1 \mathrm{~h}$ (80\%); (c) i. $\mathrm{SO}_{2} \mathrm{Cl}_{2}, \mathrm{CCl}_{4}, \mathrm{DCM}$, room temp., 1 h; ii) $\mathrm{SnCl}_{2}, \mathrm{THF}$, room temp., 2 h (11c: $80 \%$; 11d: $31 \%)$.
APA, seems to be improved when a phthalimido-protected strategy is used. ${ }^{[39]}$

To perform the epimerization steps, the sodium salt of commercial 6-APA was treated with $N$-ethoxycarbonylphthalimide and then esterified in the presence of benzyl bromide and triethylamine to obtain the protected cis$5 R, 6 R$ isomer 11a in $42 \%$ yield (for the two steps; Scheme 2). From compound 11a, epimerization at the 6position was accomplished by using a catalytic amount of the strong base 1,8-diazabicyclo[5.4.0]undec-7-ene (DBU) to give the trans-5R,6S isomer 11b in good yield ( $80 \%)$. Then the Kukolja protocol ${ }^{[40]}$ was employed to perform the epimerization at the 5-position. From the trans isomer 11b, 1 equiv. of sulfuryl chloride was used to cleave the C5-S bond of the penicillin thiazolidine ring. The trans and cis chloro derivatives were obtained in a ratio of 9:1. The mixture was then treated with anhydrous tin(II) chloride to achieve the highly trans-selective recyclization of the second cycle of the penam system. Thus, a mixture of both cis$(5 S, 6 S)-11 d(31 \%$ in two steps) and trans- $(5 R, 6 S)-11 \mathbf{b}$ isomers were obtained and separated by silica gel chromatography. Application of the two-step Kukolja protocol to the cis-5R,6R isomer 11a yielded the trans-5S,6R isomer 11c without any recovery of the starting isomer.

A last deprotection step had to be performed to realize the coupling to the decanoic peptide. Several examples of successful dephthaloylation in one step using hydrazine derivatives have been reported for monocyclic $\beta$-lactam, but only a few examples are described for bicyclic derivatives like cephalosporins, ${ }^{[39]}$ carbacephems, ${ }^{[42]}$ and isocephems. ${ }^{[43]}$ As previously reported, ${ }^{[44]}$ we observed that it was not possible to carry out efficient hydrazinolysis on penicillin derivatives without $\beta$-lactam ring-opening. The reaction performed at a lower temperature $\left(-25\right.$ to $\left.-78^{\circ} \mathrm{C}\right)$ or by using a less reactive hydrazine ( $N$-methylhydrazine) preserved the $\beta$-lactam ring but decreased the efficiency of the deprotection. To overcome this instability of the $\beta$-lactam, the phthalimido group had to be converted into a more unstable phthalisoimido group prior to hydrazinolysis. For the first time this "three-step" method ${ }^{[44]}$ was applied separately to the deprotection of the four diastereoisomers 11a-d (Scheme 3).

Compounds 11a-c were hydrolyzed to give the phthalimic acids by slow addition of 1 equiv. of aqueous sodium sulfide at $0-5{ }^{\circ} \mathrm{C}$ over $15 \mathrm{~min}$ (48-67\%; Scheme 3). Under the same basic conditions, cis- $(5 S, 6 S)$-11d appeared to be much more sensitive and unstable compared with the other isomers, probably because of a bigger strain in the bicyclic ring. To limit the degradation of the $\beta$-lactam ring, less than 1 equiv. of sodium sulfide was used as well as a careful neutralization. The phthalimic acids $\mathbf{1 2}$ were cyclized to phthalisoimides $\mathbf{1 3}$ by using $\mathrm{N}, \mathrm{N}$-dicyclohexylcarbodiimide as the activating reagent. Only the phthalisoimide form $(13 \mathbf{a}-\mathbf{c})$ was observed (by ${ }^{1} \mathrm{H}$ NMR analysis) in both the crude materials and the purified compounds (45-70\%) without any traces of the phthalimide form. However, during the synthesis of the cis- $(5 S, 6 S)-\mathbf{1 3 d}$, purification by silica gel chromatography led to the total conversion to the starting 


\section{Phtalimide deprotection and coupling step}

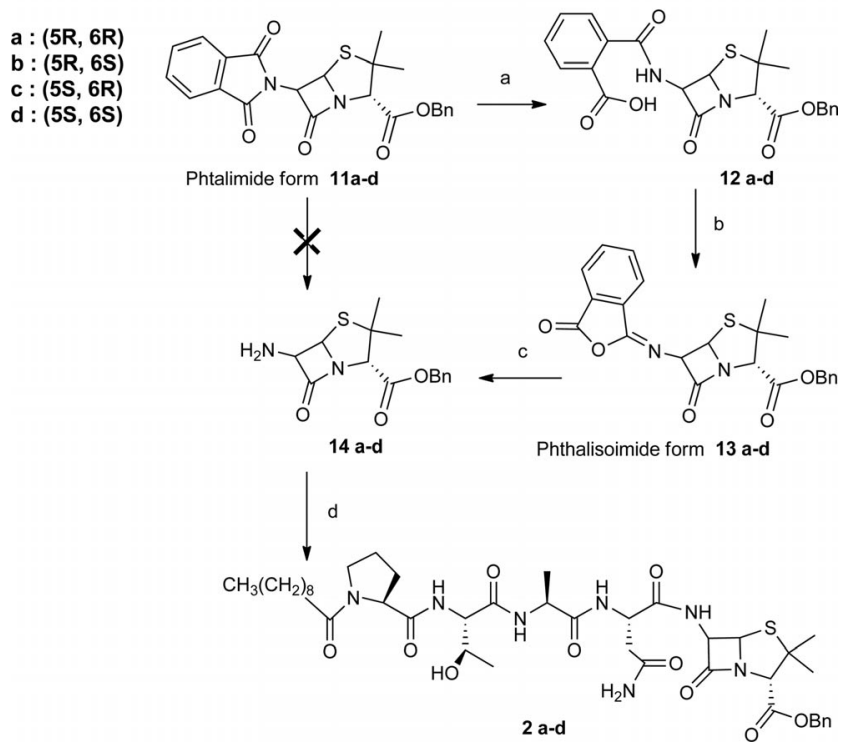

Scheme 3. Reagents and conditions: (a) $\mathrm{Na}_{2} \mathrm{~S} \cdot 9 \mathrm{H}_{2} \mathrm{O}, \mathrm{THF} / \mathrm{H}_{2} \mathrm{O}$, $0^{\circ} \mathrm{C}, 15$ min (12a: $67 \%$; 12b: 51\%; 12c: 48\%); (b) DCC, DCM, $0{ }^{\circ} \mathrm{C}, 1 \mathrm{~h}$, room temp., $1 \mathrm{~h}(13 \mathrm{a}: 70 \%$; 13b: $57 \%$; 13c: $45 \%)$; (c) $\mathrm{N}$ methylhydrazine, $\mathrm{THF},-20^{\circ} \mathrm{C}, 20 \mathrm{~min}(\mathbf{1 4 a}$ : quant.; 14b: quant.; 14c: $94 \%$; 14d: $18 \%$ from 11d); (d) Dec-PTAN-COOH (4), HOBt, EDCI, room temp., 6 h (2a: $20 \%$; 2b: $46 \%$; 2c: $70 \%$; 2d: $68 \%)$.

phthalimide form 12d, whereas only the phthalisoimide form was present in the crude material. Thus, the crude phthalisoimide cis isomer 13d was subjected to hydrazinolysis without any purification. According to the procedure described by Kukolja, the final hydrazinolysis requires a very low temperature and was carried out at $-25^{\circ} \mathrm{C}$. To avoid degradation of the $\beta$-lactam ring, $N$-methylhydrazine was used instead of hydrazine, leading to the presumed methylhydrazine adduct intermediate, ${ }^{[45]}$ which was converted into the free aminopenicillins $\mathbf{1 4 a - d}$ by intramolecular nucleophilic attack on the amido-carbonyl group.

The coupling step with the decanoyl-PTAN-COOH peptide 4 was then performed by using HOBt/EDC and afforded the four lipopeptides $\mathbf{2 a - d}$ in moderate yields. During this synthetic work we observed the $\beta$-lactam ring of the two cis isomers to be very reactive, as based on the following observations. First, the $\mathrm{MeOH}$ used as eluent during the silica gel purification was able to react and open the $\beta$-lactam ring of the cis isomers. Moreover, when more than 1 equiv. of the cis amines 14a and $\mathbf{1 4 d}$ was used during the coupling step, the formation of an additional compound was observed by mass spectrometry. This side-product resulted from nucleophilic attack of the hydroxy function of the amino acid threonine on the amide function of the $\beta$ lactam.

The inhibitory activities of the synthesized compounds were tested in vitro with the isolated signal peptidase enzyme. SPsB, the SPase I from S. aureus, was selected because the original decanoic peptide aldehyde sequence was based and designed on a consensus sequence of pre-proteins from $S$. aureus. ${ }^{[12,13]}$ The inhibitory activity of the synthe- sized compounds was evaluated by a continuous fluorimetric assay. ${ }^{[13,46]}$ This quantitative in vitro assay is based on the processing of an internally quenched fluorescent synthetic peptide substrate (FRET-based assay). After cleavage of the peptide by the SPase, an increase in the fluorescence was measured. Therefore the inhibition of SPase I can be analyzed and quantified in the presence and absence of the synthetic lipopeptides. The results of the in vitro assays on the isolated enzyme are summarized in Table 1.

Table 1. Results of the inhibitory activity assay of the synthesized lipopeptides on $S$. aureus. ${ }^{[a]}$

\begin{tabular}{lccc}
\hline Entry & Compound & Conc. $[\mu \mathrm{M}]$ & Inhibition [\%] \\
\hline 1 & $\mathbf{B}^{[\mathrm{b}]}$ & 200 & 10 \\
2 & $\mathbf{1 a}$ & 100 & 57 \\
3 & $\mathbf{1 b}$ & 100 & 47 \\
4 & $\mathbf{2 a}$ & 100 & 25 \\
5 & $\mathbf{2}^{\prime} \mathbf{a}(\mathrm{COOH})^{[\mathrm{cl}}$ & 100 & 21 \\
6 & $\mathbf{2 b}$ & 100 & 36 \\
7 & $\mathbf{2 c}$ & 100 & 12 \\
8 & $\mathbf{2 d}$ & 100 & 26 \\
9 & $\mathbf{3}$ (decanoyl-PTAN-NH & \\
\hline
\end{tabular}

[a] Concentration of the SPsB Spase I: $0.25 \mu \mathrm{M}$; concentration of the quenched peptide: $5 \mu \mathrm{M}$. Experiments were performed in duplicate. [b] Ref. ${ }^{[47]}$ [c] Deprotected form of 2a.

The biological evaluation showed the lipopeptides 1 and 2 to be moderately-to-weakly active. In each case we found that the modifications introduced into the lipopeptide did not reach the inhibition observed for the lipopeptide aldehyde (decanoyl-PTANA-COH). However, the high activity observed for the new lipopeptides $\mathbf{1}$ and $\mathbf{2}$ compared with the previously studied hydroxyethyl isoster $\mathbf{B}^{[47]}$ (entry 1 , Table 1 and Figure 3) confirms that the introduction of a $\beta$-lactam moiety at the carboxylate end seems to be a better approach to obtaining potent SPase I inhibitors. The results obtained for the $\beta$-lactam inhibitors show slight differences depending upon the compound. Indeed, the percentage inhibition obtained for the mono-bactam compounds (entries 2 and 3,57 and 47\%) appears to be two-fold higher than those obtained for the penicillin peptides (entries 4-8; $25,21,36,12$, and $26 \%$ ). This result does not correspond to the chemical reactivity of either the mono-bactam or penam as the amide function of the bicyclic derivative is usually more reactive. However, we did not consider the time frame of the inhibition experiments during the first screening assay and this study may be the subject of further investigation.

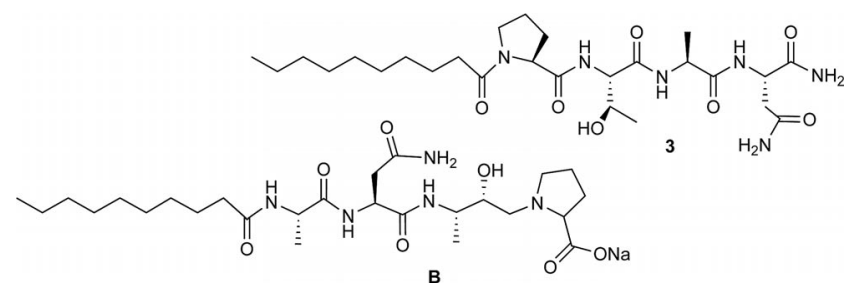

Figure 3. Additional compounds tested in the FRET-based assay on $S$. aureus sPsB. 
To eliminate the influence of solubility problems on the small differences of inhibitory activity, the deprotected carboxylic acid of 2a was synthesized (by hydrogenation) and evaluated ( $\mathbf{2}^{\prime} \mathbf{a}$, entry 5). The same percentage inhibition was obtained for both the protected and the deprotected compounds. The methyl group used as a mimic of the last alanine of the AXA sequence (present only in compounds 1a and 1b) might play a role in the recognition of the active site. To demonstrate the importance of the $\beta$-lactam moiety in the inhibition observed, decanoyl-PTAN-NH $\mathrm{N}_{2}$ (3; Figure 3) was also synthesized from peptide 4 (by treatment with ammonium chloride) and tested on SPase I SpsB. To reach the same level of inhibition as compounds $\mathbf{1}$, decanoyl-PTAN- $\mathrm{NH}_{2}$ (3; devoid of the $\beta$-lactam moiety) had to be tested at $100 \mathrm{mM}$, a concentration $10^{3}$-fold higher than that used for the lipopeptides $\mathbf{1}$. As the removal of the $\beta$ lactam moiety resulted in a complete loss of activity, this function might be implicated in the binding to the active site. However, regarding the influence of the stereochemistry of compounds $\mathbf{1}$ and $\mathbf{2}$, no significant differences were observed between the activities of the several isomers synthesized. As a consequence, the penam or the mono-bactam residue might not be ideally accommodated in the active site and for this reason only modest activities were observed with compounds $\mathbf{1}$ and $\mathbf{2}$.

Inhibition tests were also performed on the SPase I enzyme best characterized until now, the LepB of $E$. coli, the crystal structure of which was used in the modeling experiment (as the $S$. aureus SPase I has not yet been crystallized). No significant activities were observed at $10 \mathrm{~mm}$. Indeed the decanoyl-PTANA sequences appear less suitable for binding to $E$. coli SPase I than to the enzyme of Gram-positive species. However, a structural study should be performed to find the appropriate peptide sequences that would allow both to adopt a $\beta$-sheet-like conformation and to fit correctly the $\beta$-lactam ring into the active site of the SpsB enzyme. Furthermore, given the large differences in the biological activity of the peptide aldehyde ${ }^{[13]}$ and the present $\beta$-lactam conjugates, it might be hypothesized that, in addition to the non-optimal positioning in the active site, the reactivities of the $\beta$-lactam moieties of compounds of type $\mathbf{1}$ and $\mathbf{2}$ are not high enough to allow covalent bond formation. A $\beta$-lactam lipopeptide obtained from coupling between the decanoic-peptide and a penem moiety like Penem A could be a better alternative to achieve higher reactivity.

\section{Conclusions}

A new class of lipopeptides bearing a $\beta$-lactam moiety has been synthesized. This class of compounds has been poorly described and usually only the racemic form of the penicillin moiety is represented. ${ }^{[48]}$ An effort has been made to use stereoselective procedures and to obtain several diastereoisomers of the lipopeptides $\mathbf{1}$ and $\mathbf{2}$. The deprotection of the phthalimide group was performed for the first time on the four diastereoisomers of the protected 6-APA resi- due, opening the way for further asymmetric synthesis of penam compounds. In vitro studies showed moderate SPase I inhibition, which could be due to inappropriate positioning of the $\beta$-lactam in the active site. However, because the $\beta$-lactam motif seems to be involved in the inhibitory activity, other peptide sequences bearing the PTANA motif should be envisaged, as well as modifications of the $\beta$-lactam moiety, to improve the binding and reactivity with the enzyme SPsB and for the design of new potential peptidomimetic $\beta$-lactam lipopeptides.

\section{Experimental Section}

General: NMR spectra were recorded with a Bruker UltraShield $300\left({ }^{1} \mathrm{H}\right.$ : $300 \mathrm{MHz} ;{ }^{13} \mathrm{C}$ : $\left.75 \mathrm{MHz} ;{ }^{31} \mathrm{P} 121 \mathrm{MHz}\right), 500 \mathrm{MHz}\left({ }^{1} \mathrm{H}\right.$ : $500 \mathrm{MHz})$ or $600 \mathrm{MHz}\left({ }^{1} \mathrm{H}: 600 \mathrm{MHz}\right)$ spectrometer using tetramethylsilane as internal standard. Chemical shifts are reported in $\delta$ units and coupling constants ( $J$ values) in Hz. Reagents and solvents were obtained from commercial sources (Sigma-Aldrich, Acros-Organics, NovaBiochem, Alfa-Aesar and TCI Europe) and used as received (THF and DCM were used after distillation over $\mathrm{Na}$ /benzophenone and $\mathrm{CaH}_{2}$, respectively). The progress of the reaction was monitored either by TLC, performed on Alugram SIL $\mathrm{G} / \mathrm{UV}_{254}$ plates, or by mass analysis performed with a TSQ Quantum Thermo Scientific instrument. Column chromatography was performed with Grace Silicagel DAVISIL LCA $(0.040-0.063$ or $0.070-0.200 \mathrm{~mm})$. Purification on HPLC was realized with a semi-preparative Polymer Lab column, PRLPS $10 \mu \mathrm{m}$ $(21.2 \mathrm{~cm} \times 150 \mathrm{~mm}$ ID; mobile phase flow, $2 \mathrm{~mL} / \mathrm{min}$, gradient $\mathrm{H}_{2} \mathrm{O} / \mathrm{CH}_{3} \mathrm{CN}$ or $\mathrm{H}_{2} \mathrm{O} / \mathrm{CH}_{3} \mathrm{CN} / 0.1 \%$ TFA, UV detection 214/ $254 \mathrm{~nm}$ ). Optical rotations were evaluated with a Perkin-Elmer polarimeter (model 341) in chloroform. All final lipopeptide purities were checked by HRMS and HPLC. HRMS spectra were recorded with a Q-Tof-2 (Micromass, Manchester, UK) mass spectrometer. Accurate masses were determined by co-infusion of the samples with $2 \mu \mathrm{m}$ leucine enkephalin (YGGFL) and recalibration of the spectrum using the peak at $m / z=556.2771$ as the lock mass. At least 10 spectra were recorded and averaged. HPLC was performed with a Shimadzu SPD-M20A HPLC System using an intersil ODS$34 \mu \mathrm{m}(4.6 \mathrm{~cm} \times 100 \mathrm{~mm}$ ID) column. The compounds were analyzed by using $\mathrm{H}_{2} \mathrm{O} / \mathrm{CH}_{3} \mathrm{CN} / 0.1 \%$ TFA or $\mathrm{H}_{2} \mathrm{O} / \mathrm{CH}_{3} \mathrm{CN}$ solvent systems with a 30 or 35 min gradient: $5-100 \% \mathrm{CH}_{3} \mathrm{CN}$ with a flow rate of $1.0 \mathrm{~mL} / \mathrm{min}$.

Abbreviations: HOBt: hydroxybenzotriazole; DIPEA: $N$-ethyldiisopropylamine; DIC: $N^{\prime}, N^{\prime}$-diisopropylcarbodiimide; DMF: dimethylformamide; TFA: trifluoroacetic acid; EDCI: 1-ethyl-3-(3dimethylaminopropyl)carbodiimide; DCM: dichloromethane; 6APA: 6-aminopenicillanic acid; PTAN: L-prolyl-L-threonyl-L-alanyl-L-asparaginyl.

\section{Peptide Synthesis}

Decanoyl-L-prolyl-L-threonyl-L-alanyl-L-asparagine (4): The solidphase synthesis of this peptide was performed on Wang resin $(0.80 \mathrm{mg}, 0.52 \mathrm{mmol})$ following a Fmoc strategy. DMF was used as solvent, HOBt (4 equiv.), DIPEA (2 equiv.), and DIC (4 equiv.) as coupling reagents, and all the amino acids coupled were Fmocprotected. First, Fmoc-asparagine(trt) (4 equiv.) was coupled to the resin over $5 \mathrm{~h}$. After capping in the presence of acetic anhydride (20\% in pyridine) and Fmoc deprotection in the presence of piperidine (20\% in DMF), the next amino acid was coupled. The same process was performed for the coupling of Fmoc-alanine (4 equiv.), Fmoc-threonine(tbu) (4 equiv.), Fmoc-proline (4 equiv.), and then 
decanoic acid (4 equiv.). The deprotection of the lateral protecting groups and the cleavage of the resin were performed with a solution of TFA/thianisole $/ \mathrm{H}_{2} \mathrm{O}(9.5: 0.25: 0.25)$ over $3 \mathrm{~h}$. The desired peptide 4 (62 mg, 21\% in six steps) was then obtained after precipitation in diisopropyl ether and purification by preparative reversed-phase HPLC (A: $\mathrm{H}_{2} \mathrm{O} / 0.1 \%$ TFA/B: $\mathrm{CH}_{3} \mathrm{CN} / 0.1 \%$ TFA). ${ }^{1} \mathrm{H}$ NMR (300 MHz, $\mathrm{CDCl}_{3} / \mathrm{CD}_{3} \mathrm{OD}$ ): $\delta_{\mathrm{H}}=4.48[\mathrm{~m}, 1 \mathrm{H}, \mathrm{H \alpha}(\mathrm{Asn})], 4.23-$

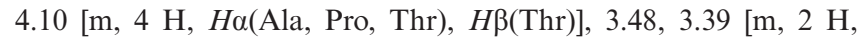
$\mathrm{CH}_{2} \delta$ (Pro)], 2.52 [m, $2 \mathrm{H}, \mathrm{CH}_{2} \beta\left(\right.$ Asn)], 2.17 [m, $2 \mathrm{H}, \mathrm{CH}_{2} \beta$ (Pro)], 1.99-1.84 [m, $4 \mathrm{H}, \mathrm{CH}_{2} \gamma($ Pro $\left.), \mathrm{CH}_{2 \text { deca }}\right], 1.41$ (m, $2 \mathrm{H}, \mathrm{CH}_{2 \text { deca }}$ ), $1.23\left[\mathrm{~d}, J=7.2 \mathrm{~Hz}, 3 \mathrm{H}, \mathrm{CH}_{3}\right.$ (Ala)], $1.14-1.05$ (m, $12 \mathrm{H}, 6 \mathrm{CH}_{2 \text { deca }}$ ), $1.01\left[\mathrm{~d}, J=6.3 \mathrm{~Hz}, 3 \mathrm{H}, \mathrm{CH}_{3}(\mathrm{Thr})\right], 0.67$ (m, $\left.3 \mathrm{H}, \mathrm{CH}_{3 \mathrm{deca}}\right) \mathrm{ppm}$. ${ }^{13} \mathrm{C}$ NMR $\left(75 \mathrm{MHz}, \mathrm{CDCl}_{3} / \mathrm{CD}_{3} \mathrm{OD}\right): \delta_{\mathrm{C}}=173.2,172.6,172.5$, 172.4, 172.3, 170.2, 66.7, 60.1, 57.8, 48.8, 47.4, 36.5, 34.3, 31.4, $29.1,29.0,28.8,28.8,24.5,24.3,22.2,18.6,16.5,13.6$ ppm. HRMS (EI): calcd. for $\mathrm{C}_{26} \mathrm{H}_{46} \mathrm{~N}_{5} \mathrm{O}_{8}[\mathrm{M}+\mathrm{H}]^{+}$556.3346; found 556,3354.

Decanoyl-L-prolyl-L-threonyl-L-alanyl-L-asparaginylcarboxamide (3): HOBt (3.60 mg, $0.02 \mathrm{mmol})$, EDCI $(5.10 \mathrm{mg}, 0.02 \mathrm{mmol})$, and then DIPEA $(12 \mu \mathrm{L}, 0.07 \mathrm{mmol})$ and $\mathrm{NH}_{4} \mathrm{Cl}(1.92 \mathrm{mg}, 0.03 \mathrm{mmol})$ were added to a solution of decanoyl-PTAN-COOH $(4 ; 10 \mathrm{mg}$, $0.02 \mathrm{mmol})$ in $\mathrm{DMF} / \mathrm{DCM}(1 \mathrm{~mL} / 1 \mathrm{~mL})$ at $0{ }^{\circ} \mathrm{C}$. The mixture was stirred for $3 \mathrm{~h}$ at room temperature and then the solvent was evaporated under reduced pressure. The crude residue was purified by preparative reversed-phase HPLC $\left(\mathrm{A}: \mathrm{H}_{2} \mathrm{O} / 0.1 \%\right.$ TFA/B: $\mathrm{CH}_{3} \mathrm{CN} /$ $0.1 \%$ TFA) to afford $3(5 \mathrm{mg}, 50 \%)$ as a white solid. ${ }^{1} \mathrm{H}$ NMR (300 MHz, $\left.\mathrm{CDCl}_{3} / \mathrm{CD}_{3} \mathrm{OD}\right): \delta_{\mathrm{H}}=4.64[\mathrm{~m}, 1 \mathrm{H}, \mathrm{H \alpha}(\mathrm{Asn})], 4.41-$

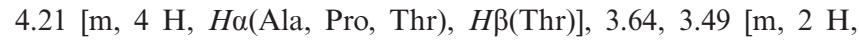
$\mathrm{CH}_{2} \delta$ (Pro)], 2.75 [m, $2 \mathrm{H}, \mathrm{CH}_{2} \beta($ Asn $\left.)\right], 2.32-2.26[\mathrm{~m}, 2 \mathrm{H}$, $\mathrm{CH}_{2} \beta$ (Pro)], 2.15-1.90 [m, $4 \mathrm{H}, \mathrm{CH}_{2} \gamma\left(\right.$ Pro), $\left.\mathrm{CH}_{2 \text { deca }}\right], 1.56$ (m, $2 \mathrm{H}$, $\left.\mathrm{CH}_{2 \text { deca }}\right), 1.35$ [d, $J=7.2 \mathrm{~Hz}, 3 \mathrm{H}, \mathrm{CH}_{3}$ (Ala)], 1.25-1.18 (m, $12 \mathrm{H}$, $\left.6 \mathrm{CH}_{2 \text { deca }}\right), 1.12\left[\mathrm{~d}, J=6.3 \mathrm{~Hz}, 3 \mathrm{H}, \mathrm{CH}_{3}(\mathrm{Thr})\right], 0.83(\mathrm{~m}, 3 \mathrm{H}$, $\mathrm{CH}_{3 \text { deca }}$ ) ppm. ${ }^{13} \mathrm{C}$ NMR $\left(75 \mathrm{MHz}, \mathrm{CDCl}_{3} / \mathrm{CD}_{3} \mathrm{OD}\right): \delta_{\mathrm{C}}=173.6$, 173.3, 173.1, 172.9, 172.5, 171.2, 66.3, 60.1, 58.1, 49.7, 49.5, 35.9, 34.0, 31.2, 28.8, 28.7, 28.6, 24.3, 24.1, 21.9, 18.6, 15.7, $13.2 \mathrm{ppm}$. HRMS (EI): calcd. for $\mathrm{C}_{26} \mathrm{H}_{47} \mathrm{~N}_{6} \mathrm{O}_{7}[\mathrm{M}+\mathrm{H}]^{+}$555.3505; found 555 . 3506.

\section{Synthesis of Lipopeptide Type 1}

(3S)-3-[(1 R)-1-(tert-Butyldimethylsilyloxy)ethyl]azetidin-2-one (5): $\mathrm{NaBH}_{4}(0.72 \mathrm{~g}, 16.10 \mathrm{mmol})$ was added to a solution of the commercial silylated azetidinone $(5 \mathrm{~g}, 17.40 \mathrm{mmol})$ in absolute ethanol $(25 \mathrm{~mL})$ at $10^{\circ} \mathrm{C}$ and the resulting suspension was kept at $10^{\circ} \mathrm{C}$ for $1 \mathrm{~h} 30 \mathrm{~min}$. Amberlite acid resin (15 g) was added to the suspension and the reaction mixture was stirred for a further $30 \mathrm{~min}$. The mixture was then filtered and the solvent was evaporated. The resulting residue was washed with ethyl acetate and several times with DCM. The filtrates were combined and the solvents were removed under reduced pressure. The residue obtained was purified by chromatography on silica gel using DCM/ethyl acetate $(9.5: 0.5)$ as eluent to give $5(3.23 \mathrm{~g}, 81 \%)$ as a white solid. $R_{\mathrm{f}}=0.3(\mathrm{DCM} /$ ethyl acetate, 9.5:0.5). ${ }^{1} \mathrm{H}$ NMR $\left(300 \mathrm{MHz}, \mathrm{CDCl}_{3}\right): \delta_{\mathrm{H}}=5.67$ (br., $1 \mathrm{H}, \mathrm{N} H), 4.22(\mathrm{qd}, J=4.7, J=6.2 \mathrm{~Hz}, 1 \mathrm{H}, 5-\mathrm{H}), 3.36(\mathrm{dd}, J=$ 2.7, $J=5.0 \mathrm{~Hz}, 1 \mathrm{H}, 4-\mathrm{Ha}), 3.29(\mathrm{t}, J=5.0 \mathrm{~Hz}, 1 \mathrm{H}, 4-\mathrm{Hb}), 3.29$ $(\mathrm{m}, 1 \mathrm{H}, 3-\mathrm{H}), 1.20(\mathrm{~d}, J=6.2 \mathrm{~Hz}, 3 \mathrm{H}, 6-\mathrm{H}), 0.88[\mathrm{~s}, 9 \mathrm{H}$, $\left.\left(\mathrm{CH}_{3}\right)_{3} \mathrm{C}\right], 0.08 \quad\left[\mathrm{~s}, 6 \mathrm{H},\left(\mathrm{CH}_{3}\right)_{2} \mathrm{Si}\right] \mathrm{ppm} .{ }^{13} \mathrm{C} \mathrm{NMR}(75 \mathrm{MHz}$, $\left.\mathrm{CDCl}_{3}\right): \delta_{\mathrm{C}}=169.2,64.9,59.0,37.3,25.4,22.2,17.6,-4.6$, $-5.3 \mathrm{ppm}$. HRMS (EI): calcd. for $\mathrm{C}_{11} \mathrm{H}_{24} \mathrm{NO}_{2} \mathrm{Si}[\mathrm{M}+\mathrm{H}]^{+}$ 230.1576; found 230.1567 .

(3S)-3-[(1 R)-1-Hydroxyethyl]azetidin-2-one $\quad(6 a):$ Compound 5 $(0.50 \mathrm{~g}, 2.20 \mathrm{mmol})$ was dissolved in $\mathrm{CH}_{3} \mathrm{CN}(12 \mathrm{~mL})$, and $1 \mathrm{~N} \mathrm{HCl}$ $(2 \mathrm{~mL})$ was added. The reaction was monitored by TLC and after $1 \mathrm{~h} 30 \mathrm{~min}$ another $1 \mathrm{~N} \mathrm{HCl}(0.50 \mathrm{~mL})$ was added to afford total deprotection. After $30 \mathrm{~min}$, the mixture was neutralized by the slow addition of a $1 \mathrm{~N} \mathrm{NaOH}$ solution. The solvents were removed under reduced pressure and the residue obtained was purified by chromatography on silica gel using DCM/ethyl acetate/MeOH $(10: 10: 0.3)$ as eluent to give $\mathbf{6 a}(194 \mathrm{mg}, 77 \%)$ as a white solid. $R_{\mathrm{f}}$ $=0.2(\mathrm{DCM} / \mathrm{MeOH}, 9.5: 0.5) .{ }^{1} \mathrm{H}$ NMR $\left(300 \mathrm{MHz},\left[\mathrm{D}_{6}\right] \mathrm{DMSO}\right)$ : $\delta_{\mathrm{H}}=7.68$ (br., $\left.1 \mathrm{H}, \mathrm{N} H\right), 4.78(\mathrm{~d}, J=5.1 \mathrm{~Hz}, 1 \mathrm{H}, \mathrm{OH}), 3.80(\mathrm{dq}$, $J=5.4, J=6.3 \mathrm{~Hz}, 1 \mathrm{H}, 5-\mathrm{H}), 3.14(\mathrm{t}, J=5.4 \mathrm{~Hz}, 1 \mathrm{H}, 4-\mathrm{Hb})$, 3.06-3.00 (m, 2 H, 4-Ha, 3-H), 1.11 (d, $J=6.3 \mathrm{~Hz}, 3 \mathrm{H}, 6-\mathrm{H}) \mathrm{ppm}$. ${ }^{13} \mathrm{C}$ NMR (75 MHz, [D $]$ DMSO): $\delta_{\mathrm{C}}=168.9,64.5,58.6,37.6$, 22.1 ppm. HRMS (EI): calcd. for $\mathrm{C}_{5} \mathrm{H}_{10} \mathrm{NO}_{2}[\mathrm{M}+\mathrm{H}]^{+}$116.0711; found 116.0704 .

(3S)-3-[(1S)-1-(Benzoyloxy)ethyl]azetidin-2-one (6'): Tributylphosphane $(0.16 \mathrm{~mL}, 0.65 \mathrm{mmol})$ and benzoic acid $(53 \mathrm{mg}, 0.43 \mathrm{mmol})$ were added at $0{ }^{\circ} \mathrm{C}$ to a solution of the azetidinone $6 \mathbf{6}(50 \mathrm{mg}$, $0.43 \mathrm{mmol})$ in dry toluene $(3 \mathrm{~mL})$. Then $N^{\prime}, N^{\prime}, N^{\prime}, N^{\prime}$-tetramethylazodicarboxamide (TMAD; $112 \mathrm{mg}, 0.65 \mathrm{mmol}$ ) was added in one portion. The reaction mixture was stirred at $0{ }^{\circ} \mathrm{C}$ for $10 \mathrm{~min}$ and then at $60^{\circ} \mathrm{C}$ for $1 \mathrm{~d}$. Dihydro-TMAD was precipitated and filtered off after the addition of hexane to the reaction mixture. The solvents were removed under reduced pressure and the resulting residue was purified by chromatography on silica gel using hexane/ethyl acetate (8.5:1.5) as eluent to give $\mathbf{6}^{\prime}(35 \mathrm{mg}, 35 \%)$ as a white amorphous solid. $R_{\mathrm{f}}=0.3$ (hexane/ethyl acetate, $\left.3: 7\right) .{ }^{1} \mathrm{H}$ NMR $\left(300 \mathrm{MHz}, \mathrm{CDCl}_{3}\right): \delta_{\mathrm{H}}=8.06\left(\mathrm{~d}, J=7.2 \mathrm{~Hz}, 2 \mathrm{H}, H_{o} \mathrm{Bz}\right)$, $7.58\left(\mathrm{t}, J=7.2 \mathrm{~Hz}, 2 \mathrm{H}, H_{p} \mathrm{Bz}\right), 7.45\left(\mathrm{t}, J=7.2 \mathrm{~Hz}, 2 \mathrm{H}, H_{m} \mathrm{Bz}\right)$, 5.92 (br., $1 \mathrm{H}, \mathrm{N} H$ ), 4.07 (qd, $J=4.0, J=6.3 \mathrm{~Hz}, 1 \mathrm{H}, 5-\mathrm{H}$ ), 3.61 (m, $1 \mathrm{H}, 3-\mathrm{H}), 3.42(\mathrm{t}, J=5.7 \mathrm{~Hz}, 1 \mathrm{H}, 4-\mathrm{Hb}), 3.23(\mathrm{dd}, J=2.7, J$ $=5.7 \mathrm{~Hz}, 1 \mathrm{H}, 4-\mathrm{Ha}), 1.57(\mathrm{~d}, J=6.3 \mathrm{~Hz}, 3 \mathrm{H}, 6-\mathrm{H}) \mathrm{ppm} .{ }^{13} \mathrm{C}$ NMR $\left(75 \mathrm{MHz}, \mathrm{CDCl}_{3}\right): \delta_{\mathrm{C}}=167.5,165.6,132.6,129.7,129.3$, 128.1, 67.5, 55.3, 37.9, $17.2 \mathrm{ppm}$. HRMS (EI): calcd. for $\mathrm{C}_{12} \mathrm{H}_{14} \mathrm{NO}_{3}[\mathrm{M}+\mathrm{H}]^{+}$220.0973; found 220.0978.

(3S)-3-[(1S)-1-Hydroxyethyl]azetidin-2-one (6b): A 0.5 m solution of $\mathrm{NaOH}(0.05 \mathrm{~mL}, 0.09 \mathrm{mmol})$ was added at room temperature to a solution of $\mathbf{6}^{\prime}(20 \mathrm{mg}, 0.09 \mathrm{mmol})$ in $\mathrm{MeOH}(4 \mathrm{~mL})$. The reaction mixture was stirred overnight and a further 1 equiv of $\mathrm{NaOH}$ $(0.05 \mathrm{~mL}, 0.09 \mathrm{mmol})$ was added. The reaction mixture was stirred for $40 \mathrm{~min}$ and then neutralized with an excess of acetic acid. The solvents were removed under reduced pressure and the residue obtained was purified by chromatography on silica gel using ethyl acetate/DCM/MeOH $(50: 50: 0.4)$ as eluent to give $\mathbf{6 b}(7.50 \mathrm{mg}$, $70 \%$ ) as a white solid. $R_{\mathrm{f}}=0.3$ (ethyl acetate/MeOH, 9.5:0.5). ${ }^{1} \mathrm{H}$ NMR (300 MHz, $\mathrm{CDCl}_{3}$ ): $\delta_{\mathrm{H}}=6.43$ (br., $1 \mathrm{H}, \mathrm{NH}$ ), 4.07 (quint., $J=6.3 \mathrm{~Hz}, 1 \mathrm{H}, 5-\mathrm{H}), 3.37$ (t, $J=5.4 \mathrm{~Hz}, 1 \mathrm{H}, 4-\mathrm{Hb}), 3.30-3.25$ (m, $1 \mathrm{H}, 3-\mathrm{H}), 3.18$ (dd, $J=2.4, J=5.4 \mathrm{~Hz}, 1 \mathrm{H}, 4-\mathrm{Ha}$ ), 2.95 (br., $1 \mathrm{H}, \mathrm{OH}), 1.31(\mathrm{~d}, J=6.3 \mathrm{~Hz}, 3 \mathrm{H}, 6-\mathrm{H}) \mathrm{ppm} .{ }^{13} \mathrm{C}$ NMR $(75 \mathrm{MHz}$, $\mathrm{CDCl}_{3}$ ): $\delta_{\mathrm{C}}=170.1,65.6,57.4,38.2,20.6$ ppm. HRMS (EI): calcd. for $\mathrm{C}_{5} \mathrm{H}_{10} \mathrm{NO}_{2}[\mathrm{M}+\mathrm{H}]^{+}$116.0711; found 116.0715.

(3S)-3-[(1R)-1-(Methylsulfonyloxy)ethyl|azetidin-2-one (7a): Methanesulfonyl chloride $(0.15 \mathrm{~mL}, 1.90 \mathrm{mmol})$ was added to a solution of the alcohol $6 \mathbf{6 a}(150 \mathrm{mg}, 1.30 \mathrm{mmol})$ in dry pyridine at $0{ }^{\circ} \mathrm{C}$. The reaction mixture was stirred at $0^{\circ} \mathrm{C}$ for $1 \mathrm{~h} 30 \mathrm{~min}$ and an additional 1.5 equiv. of methanesulfonyl chloride was added. The reaction mixture was stirred for $1 \mathrm{~h}$ to reach completion of the reaction. After evaporation of the solvent, the residue obtained was dissolved in DCM and washed with water and brine. The aqueous phase was extracted several times with DCM. The organic phases were combined, dried $\left(\mathrm{MgSO}_{4}\right)$, and concentrated in vacuo. The residue obtained was purified by chromatography on silica gel using hexane/ethyl acetate (2:8) as eluent to give $7 \mathbf{a}(250 \mathrm{mg}, 99 \%)$ as a white solid. $R_{\mathrm{f}}=0.4$ (ethyl acetate). ${ }^{1} \mathrm{H} \mathrm{NMR}(300 \mathrm{MHz}$, $\mathrm{CDCl}_{3}$ ): $\delta_{\mathrm{H}}=5.81$ (br., $1 \mathrm{H}, \mathrm{NH}$ ), 5.08 (quint., $J=6.3 \mathrm{~Hz}, 1 \mathrm{H}$, 5-H), 3.50-3.43 (m, $3 \mathrm{H}, 4-\mathrm{H}, 3-\mathrm{H}), 3.06\left(\mathrm{~s}, 3 \mathrm{H}, \mathrm{CH}_{3} \mathrm{SO}_{2}\right), 1.57$ 
(d, $J=6.3 \mathrm{~Hz}, 3 \mathrm{H}, 6-\mathrm{H}) \mathrm{ppm} .{ }^{13} \mathrm{C}$ NMR $\left(75 \mathrm{MHz}, \mathrm{CDCl}_{3}\right): \delta_{\mathrm{C}}$ $=166.1,76.2,56.4,38.5,38.2,19.7$ ppm. HRMS (EI): calcd. for $\mathrm{C}_{6} \mathrm{H}_{12} \mathrm{NO}_{4} \mathrm{~S}[\mathrm{M}+\mathrm{H}]^{+}$194.0486; found 194.0494.

(3S)-3-[(1S)-1-(Methylsulfonyloxy)ethyl|azetidin-2-one (7b): The same process was used starting from the alcohol $\mathbf{6 b}(30 \mathrm{mg}$, $0.26 \mathrm{mmol})$ and afforded the mesylate $7 \mathbf{b}(30 \mathrm{mg}, 60 \%)$ as a white solid after purification by chromatography on silica gel using hexane/ethyl acetate (2:8) as eluent. $R_{\mathrm{f}}=0.3$ (ethyl acetate). ${ }^{1} \mathrm{H}$ NMR $\left(500 \mathrm{MHz}, \mathrm{CDCl}_{3}\right): \delta_{\mathrm{H}}=5.98$ (br., $\left.1 \mathrm{H}, \mathrm{NH}\right), 5.12$ (quint., $J=$ $6.5 \mathrm{~Hz}, 1 \mathrm{H}, 5-\mathrm{H}), 3.57(\mathrm{~m}, 1 \mathrm{H}, 3-\mathrm{H}), 3.45(\mathrm{t}, J=6.0 \mathrm{~Hz}, 1 \mathrm{H}, 4-$ $\mathrm{Hb}$ ), 3.35 (dd, $J=2.5, J=6.0 \mathrm{~Hz}, 4-\mathrm{Ha}), 3.10$ (s, $3 \mathrm{H}, \mathrm{CH}_{3} \mathrm{SO}_{2}$ ), $1.62(\mathrm{~d}, J=6.5 \mathrm{~Hz}, 3 \mathrm{H}, 6-\mathrm{H}) \mathrm{ppm} .{ }^{13} \mathrm{C} \mathrm{NMR}\left(75 \mathrm{MHz}, \mathrm{CDCl}_{3}\right)$ : $\delta_{\mathrm{C}}=166.3,74.9,55.3,38.6,37.7,18.4$ ppm. HRMS (EI): calcd. for $\mathrm{C}_{6} \mathrm{H}_{12} \mathrm{NO}_{4} \mathrm{~S}[\mathrm{M}+\mathrm{H}]^{+}$194.0486; found 194.0492.

(3S)-3-[(1S)-1-Azidoethyl]azetidin-2-one $\quad$ (8a): $\quad \mathrm{LiN}_{3} \quad(8.07 \mathrm{mg}$, $0.16 \mathrm{mmol})$ was added to a solution of the mesylate $7 \mathbf{a}(22 \mathrm{mg}$, $0.11 \mathrm{mmol}$ ) in dry DMF at room temperature. The reaction mixture was stirred overnight at $60^{\circ} \mathrm{C}$ and the solvent was evaporated under reduced pressure. The residue obtained was dissolved in DCM and washed with water and brine. The aqueous phase was extracted several times with DCM. The organic phases were combined, dried $\left(\mathrm{MgSO}_{4}\right)$, and concentrated in vacuo. The residue obtained was purified by chromatography on silica gel using hexane/ ethyl acetate (3:7) as eluent to give $\mathbf{8 a}(13 \mathrm{mg}, 81 \%)$ as an amorphous solid. $R_{\mathrm{f}}=0.5$ (ethyl acetate). ${ }^{1} \mathrm{H}$ NMR $\left(300 \mathrm{MHz}, \mathrm{CDCl}_{3}\right)$ : $\delta_{\mathrm{H}}=6.38$ (br., $\left.1 \mathrm{H}, \mathrm{N} H\right), 3.87$ (qd, $\left.J=6.6, J=5.1 \mathrm{~Hz}, 1 \mathrm{H}, 5-\mathrm{H}\right)$, $3.42-3.38$ (m, $1 \mathrm{H}, 3-\mathrm{H}), 3.37$ (t, $J=5.6 \mathrm{~Hz}, 1 \mathrm{H}, 4-\mathrm{Hb}), 3.21$ (dd, $J=2.1, J=5.6 \mathrm{~Hz}, 4-\mathrm{Ha}), 1.43(\mathrm{~d}, J=6.6 \mathrm{~Hz}, 3 \mathrm{H}, 6-\mathrm{H}) \mathrm{ppm}$. ${ }^{13} \mathrm{C}$ NMR $\left(75 \mathrm{MHz}, \mathrm{CDCl}_{3}\right): \delta_{\mathrm{C}}=167.9,55.2,54.7,37.8$, 16.2 ppm. HRMS (EI): calcd. for $\mathrm{C}_{5} \mathrm{H}_{9} \mathrm{~N}_{4} \mathrm{O}[\mathrm{M}+\mathrm{H}]^{+}$141.0776; found 141.0787 .

(3S)-3-[(1R)-1-Azidoethyl]azetidin-2-one (8b): The same process was used starting from the mesylate $7 \mathbf{b}(24 \mathrm{mg}, 0.12 \mathrm{mmol})$ and afforded compound $\mathbf{8 b}(14 \mathrm{mg}, 80 \%)$ as an amorphous solid after purification by chromatography on silica gel using hexane/ethyl acetate (4:6) as eluent. $R_{\mathrm{f}}=0.5$ (ethyl acetate). ${ }^{1} \mathrm{H}$ NMR $(300 \mathrm{MHz}$, $\mathrm{CDCl}_{3}$ ): $\delta_{\mathrm{H}}=5.99$ (br., $1 \mathrm{H}, \mathrm{N} H$ ), 3.90 (quint., $J=6.6 \mathrm{~Hz}, 1 \mathrm{H}$, 5-H), 3.43 (m, $1 \mathrm{H}, 4-\mathrm{H}), 3.30-3.24$ (m, $2 \mathrm{H}, 4-\mathrm{H}, 3-\mathrm{H}), 1.43$ (d, J $=6.6 \mathrm{~Hz}, 3 \mathrm{H}, 6-\mathrm{H}) \mathrm{ppm} .{ }^{13} \mathrm{C} \mathrm{NMR}\left(75 \mathrm{MHz}, \mathrm{CDCl}_{3}\right): \delta_{\mathrm{C}}=167.6$, 56.2, 55.8, 38.8, 17.4 ppm. HRMS (EI): calcd. for $\mathrm{C}_{5} \mathrm{H}_{8} \mathrm{~N}_{4} \mathrm{ONa}[\mathrm{M}$ $+\mathrm{Na}]^{+}$163.0596; found 163.0582 .

(3S)-3-[(1S)-1-Aminoethyl]azetidin-2-one (9a): Compound 8a (43 mg, $0.30 \mathrm{mmol}$ ) was hydrogenated in $\mathrm{MeOH}(4 \mathrm{~mL})$ under atmospheric pressure on $10 \%$ palladium on carbon $(15 \mathrm{mg})$ for $3 \mathrm{~h}$. The catalyst was filtered and washed with $\mathrm{MeOH}$. The filtrate was concentrated under reduced pressure to afford compound 9a (28 mg, 80\%) as a white solid. $R_{\mathrm{f}}=0.2(\mathrm{DCM} / \mathrm{MeOH}, 8: 2) .{ }^{1} \mathrm{H}$ NMR (300 MHz, [D $]$ DMSO): $\delta_{\mathrm{H}}=7.70$ (br., $1 \mathrm{H}, \mathrm{NH}$ ), 3.32 (br., $\left.2 \mathrm{H}, \mathrm{N} H_{2}\right), 3.14-2.92(\mathrm{~m}, 4 \mathrm{H}, 5-\mathrm{H}, 4-\mathrm{H}, 3-\mathrm{H}), 0.99$ (d, $J=6.3 \mathrm{~Hz}$, $3 \mathrm{H}, 6-\mathrm{H}) \mathrm{ppm} .{ }^{13} \mathrm{C} \mathrm{NMR}\left(75 \mathrm{MHz}, \mathrm{CDCl}_{3}\right): \delta_{\mathrm{C}}=170.1,58.3$, 46.2, 37.5, 21.3 ppm. HRMS (EI): calcd. for $\mathrm{C}_{5} \mathrm{H}_{10} \mathrm{~N}_{2} \mathrm{O}[\mathrm{M}+\mathrm{H}]^{+}$ 115.0871; found 115.0876 .

(3S)-3-I(1R)-1-Aminoethyl|azetidin-2-one (9b): The same process as described for the synthesis of $\mathbf{9 a}$ was used to obtain the amine $\mathbf{9 b}$ (20 $\mathrm{mg}, 84 \%)$ as a white solid from compound $\mathbf{8 b}(29 \mathrm{mg}$, $0.20 \mathrm{mmol}) . R_{\mathrm{f}}=0.2(\mathrm{DCM} / \mathrm{MeOH}, 8: 2) .{ }^{1} \mathrm{H} \mathrm{NMR}(300 \mathrm{MHz}$, $\left.\mathrm{D}_{2} \mathrm{O}\right): \delta_{\mathrm{H}}=3.37-3.43(\mathrm{~m}, 1 \mathrm{H}, 5-\mathrm{H}), 3.20-3.12(\mathrm{~m}, 3 \mathrm{H}, 4-\mathrm{H}, 3-$ $\mathrm{H}), 1.08(\mathrm{~d}, J=6.0 \mathrm{~Hz}, 3 \mathrm{H}, 6-\mathrm{H}) \mathrm{ppm} .{ }^{13} \mathrm{C} \mathrm{NMR}(75 \mathrm{MHz}$, $\mathrm{CDCl}_{3}$ ): $\delta_{\mathrm{C}}=172.8,56.6,44.8,38.7,19.3 \mathrm{ppm}$. HRMS (EI): calcd. for $\mathrm{C}_{5} \mathrm{H}_{10} \mathrm{~N}_{2} \mathrm{O}[\mathrm{M}+\mathrm{H}]^{+}$115.0871; found 115.0869.
(3S)-3-\{(1R)-1-I( $N$-Decanoyl-L-prolyl-L-threonyl-L-alanyl-L-asparaginyl)amino]ethyl azetidin-2-one (1a): Decanoyl-PTAN-COOH (4; $15 \mathrm{mg}, 0.03 \mathrm{mmol})$ and the aminoazetidinone $9 \mathrm{a}(3 \mathrm{mg}, 0.03 \mathrm{mmol})$ were dissolved in dry DMF $(1.5 \mathrm{~mL})$ and the solution was cooled to $0{ }^{\circ} \mathrm{C}$. HOBt (5.40 mg, $\left.0.04 \mathrm{mmol}\right)$, EDCI (10.20 mg, $\left.0.06 \mathrm{mmol}\right)$, and then DIPEA $(12 \mu \mathrm{L}, 0.06 \mathrm{mmol})$ were added to the solution and the reaction was stirred at room temperature for $6 \mathrm{~h}$. The solvent was then evaporated to dryness under vacuum. The residue obtained was dissolved in DCM and washed successively with citric acid solution $(1 \mathrm{M})$ and brine. The aqueous phases were extracted several times with DCM and the resulting organic phases were combined, dried, and concentrated under vacuum. The residue obtained was purified by chromatography on silica gel using DCM/ $\mathrm{MeOH}(9.5: 0.5$ to $8: 2)$ as eluent to give $1 \mathrm{a}(11 \mathrm{mg}, 62 \%)$ as a white solid contaminated by the $3 R$ isomer. Major product: $R_{\mathrm{f}}=0.5$ (DCM/MeOH, 9:1). ${ }^{1} \mathrm{H}$ NMR $\left(300 \mathrm{MHz}, \mathrm{CDCl}_{3}\right): \delta_{\mathrm{H}}=4.62[\mathrm{~m}, 1$ $\mathrm{H}, H \alpha(\mathrm{Asn})$ ], 4.46-4.20 [m, $4 \mathrm{H}, H \alpha$ (Ala, Pro, Thr), $H \beta(\mathrm{Thr})], 3.69$, 3.54 [m, $2 \mathrm{H}, \mathrm{CH}_{2} \delta$ (Pro)], 3.45-3.15 (m, $\left.4 \mathrm{H}, 5-\mathrm{H}, 4-\mathrm{H}, 3-\mathrm{H}\right), 2.68$ [m, $2 \mathrm{H}, \mathrm{CH}_{2} \beta($ Asn $)$ ], 2.40-2.00 [m, $6 \mathrm{H}, \mathrm{CH}_{2} \beta$ (Pro), $\mathrm{CH}_{2} \gamma$ (Pro), $\left.\mathrm{CH}_{2 \text { deca }}\right], 1.60\left(\mathrm{~m}, 2 \mathrm{H}, \mathrm{CH}_{2 \text { deca }}\right), 1.44[\mathrm{~d}, J=7.2 \mathrm{~Hz}, 3 \mathrm{H}$, $\mathrm{CH}_{3}$ (Ala)], 1.30 (d, $\left.J=7.2 \mathrm{~Hz}, 3 \mathrm{H}, 6-\mathrm{H}\right), 1.28-1.17(\mathrm{~m}, 12 \mathrm{H}$, $\left.6 \mathrm{CH}_{2 \text { deca }}\right), 1.21$ [d, $\left.J=6.0 \mathrm{~Hz}, 3 \mathrm{H}, \mathrm{CH}_{3}(\mathrm{Thr})\right], 0.87(\mathrm{~m}, 3 \mathrm{H}$, $\mathrm{CH}_{3 \text { deca }}$ ) ppm. ${ }^{13} \mathrm{C}$ NMR $\left(75 \mathrm{MHz}, \mathrm{CDCl}_{3}\right): \delta_{\mathrm{C}}=173.5,172.7$, $172.4,171.5,171.0,169.7,167.0,66.9,60.2,58.1,55.7,50.2,50.1$, $47.3,43.6,38.5,36.0,34.3,31.4,29.0,28.9,28.8,28.7,24.5,24.3$, 22.2, 19.2, 17.1, 16.1, $13.6 \mathrm{ppm}$. HRMS (EI): calcd. for $\mathrm{C}_{31} \mathrm{H}_{54} \mathrm{~N}_{7} \mathrm{O}_{8}[\mathrm{M}+\mathrm{H}]^{+}$652.4033; found 652.4017.

(3S)-3-\{(1S)-1-I(N-Decanoyl-L-prolyl-L-threonyl-L-alanyl-Lasparaginyl)aminolethyl azetidin-2-one (1b): Decanoyl-PTAN$\mathrm{COOH}(4 ; 15 \mathrm{mg}, 0.03 \mathrm{mmol})$, and the aminoazetidinone $\mathbf{9 b}(3 \mathrm{mg}$, $0.03 \mathrm{mmol})$ were dissolved in dry DMF $(1.50 \mathrm{~mL})$ and the solution was cooled to $0{ }^{\circ} \mathrm{C}$. HOBt $(5.40 \mathrm{mg}, 0.04 \mathrm{mmol})$, EDCI $(10.20 \mathrm{mg}$, $0.06 \mathrm{mmol})$, and then DIPEA $(12 \mu \mathrm{L}, 0.06 \mathrm{mmol})$ were added to the solution and the reaction mixture was stirred at room temperature for $6 \mathrm{~h}$. The solvent was then evaporated to dryness under vacuum. The residue obtained was dissolved in DCM and washed successively with citric acid solution (1 M) and brine. The aqueous phases were extracted several times with DCM and the resulting organic phases were combined, dried, and concentrated under vacuum. The residue obtained was purified by chromatography on silica gel using DCM/MeOH (9.5:0.5 to 8:2) as eluent to give $\mathbf{1 b}$ $(8 \mathrm{mg}, 45 \%)$ as a white solid. $R_{\mathrm{f}}=0.5(\mathrm{DCM} / \mathrm{MeOH}, 9: 1) .{ }^{1} \mathrm{H}$ NMR (300 MHz, $\left.\mathrm{CDCl}_{3} / \mathrm{CD}_{3} \mathrm{OD}\right): \delta_{\mathrm{H}}=4.58$ [m, $\left.1 \mathrm{H}, \mathrm{H \alpha}(\mathrm{Asn})\right]$, 4.38-4.17 [m, 4 H, Ha(Ala, Pro, Thr), $H \beta(\mathrm{Thr})], 3.65,3.51$ [m, 2 $\mathrm{H}, \mathrm{CH}_{2} \delta$ (Pro)], 3.25 (m, $\left.1 \mathrm{H}, 5-\mathrm{H}\right), 3.15-2.64$ (m, $\left.3 \mathrm{H}, 4-\mathrm{H}, 3-\mathrm{H}\right)$, 2.66 [m, $2 \mathrm{H}, \mathrm{CH}_{2} \beta\left(\right.$ Asn)], 2.22 [m, $2 \mathrm{H}, \mathrm{CH}_{2} \beta$ (Pro)], 2.20-1.90 [m, $4 \mathrm{H}, \mathrm{CH}_{2} \gamma($ Pro $\left.), \mathrm{CH}_{2 \text { deca }}\right], 1.56\left(\mathrm{~m}, 2 \mathrm{H}, \mathrm{CH}_{2 \text { deca }}\right), 1.39$ [d, $J=$ $\left.6.0 \mathrm{~Hz}, 3 \mathrm{H}, \mathrm{CH}_{3}(\mathrm{Ala})\right], 1.34-1.17$ (m, $\left.15 \mathrm{H}, 6-\mathrm{H}, 6 \mathrm{CH}_{2 \text { deca }}\right), 1.14$ $\left[\mathrm{d}, J=6.0 \mathrm{~Hz}, 3 \mathrm{H}, \mathrm{CH}_{3}(\mathrm{Thr})\right], 0.80(\mathrm{t}, J=6.9 \mathrm{~Hz}, 3 \mathrm{H}$, $\mathrm{CH}_{3 \text { deca }}$ ) ppm. ${ }^{13} \mathrm{C} \mathrm{NMR}\left(75 \mathrm{MHz}, \mathrm{CDCl}_{3}\right): \delta_{\mathrm{C}}=173.8,173.2$, $172.8,172.4,171.1,170.3,166.8,66.1,60.5,58.1,55.0,50.4,50.1$, $47.4,42.9,38.0,36.4,34.3,31.4,29.1,29.0,28.9,24.6,24.3,22.2$, 19.1, 17.2, 16.2, 13.6 ppm. HRMS (EI): calcd. for $\mathrm{C}_{31} \mathrm{H}_{54} \mathrm{~N}_{7} \mathrm{O}_{8}[\mathrm{M}$ $+\mathrm{H}]^{+}$652.4033; found 652.4019 .

\section{Synthesis of Lipopeptides Type 2}

(2S,5R,6R)-3,3-Dimethyl-7-oxo-6-phthalimido-4-thia-1-azabicyclo[3.2.0]heptane-2-carboxylic Acid (10): $N$-(Ethoxycarbonyl)phthalimide $(5.07 \mathrm{~g}, 23 \mathrm{mmol})$ was added to a vigorously stirred solution of 6-aminopenicillanic acid (6-APA; $5 \mathrm{~g}, 23 \mathrm{mmol}$ ) and $\mathrm{Na}_{2} \mathrm{CO}_{3}$ $(2.45 \mathrm{~g}, 23 \mathrm{mmol})$ in water $(35 \mathrm{~mL})$. The mixture was stirred at room temperature for $3 \mathrm{~h}$ and then extracted with DCM. The aqueous layer was mixed with a fresh portion of DCM and acidified 
during vigorous stirring with $1 \mathrm{M} \mathrm{HCl}(46 \mathrm{~mL}, 46 \mathrm{mmol})$. The phases were separated and the extraction was completed with two additional portions of DCM. The combined organic extracts were washed with water and brine. The organic layer was dried $\left(\mathrm{MgSO}_{4}\right)$ and concentrated under reduced pressure to afford compound $\mathbf{1 0}$ $(5.64 \mathrm{~g}, 70 \%)$ as a white solid, which was used in the next step without further purification. An analytical sample was obtained as a white crystalline solid by crystallization from acetone. $R_{\mathrm{f}}=0.5$ (DCM/MeOH, 8:2). ${ }^{1} \mathrm{H}$ NMR $\left(300 \mathrm{MHz}, \mathrm{CDCl}_{3}\right): \delta_{\mathrm{H}}=7.92-7.77$ (m, $4 \mathrm{H}, H \mathrm{pht}), 5.70$ and $5.61(2 \times \mathrm{d}, J=3.9 \mathrm{~Hz}, 2 \times 1 \mathrm{H}, 5-\mathrm{H}, 6-$ $\mathrm{H}), 4.71$ (s, $1 \mathrm{H}, 2-\mathrm{H}), 1.85$ (s, $\left.3 \mathrm{H}, \mathrm{CH}_{3}\right), 1.62$ (s, $\left.3 \mathrm{H}, \mathrm{CH}_{3}\right) \mathrm{ppm}$. ${ }^{13} \mathrm{C} \mathrm{NMR}\left(75 \mathrm{MHz}, \mathrm{CDCl}_{3}\right): \delta_{\mathrm{C}}=171.1,168.5,166.2,134.2,131.1$, 123.6, 70.6, 66.3, 65.3, 57.9, 30.1, 27.7 ppm. HRMS (EI): calcd. for $\mathrm{C}_{16} \mathrm{H}_{15} \mathrm{~N}_{2} \mathrm{O}_{5} \mathrm{~S}[\mathrm{M}+\mathrm{H}]^{+} 347.0701$; found 347.0706.

Benzyl (2S,5R,6R)-3,3-Dimethyl-7-oxo-6-phthalimido-4-thia-1-azabicyclo[3.2.0|heptane-2-carboxylate (11a): Triethylamine $(1.30 \mathrm{~mL}$, $9.39 \mathrm{mmol})$ followed by benzyl bromide $(1.46 \mathrm{~mL}, 12.20 \mathrm{mmol})$ were added to a stirred solution of acid $\mathbf{1 0}(3.25 \mathrm{~g}, 9.39 \mathrm{mmol})$ in dry DMF $(20 \mathrm{~mL})$. The mixture was stirred at room temperature for $6 \mathrm{~h}$ and then poured into vigorously stirred ice-water $(150 \mathrm{~mL})$. The resulting suspension was extracted three times with chloroform and the combined organic layers were successively washed with a saturated solution of $\mathrm{NaHCO}_{3}(\times 3)$, water $(\times 3)$, and brine. The organic phases were dried $\left(\mathrm{MgSO}_{4}\right)$ and concentrated under reduced pressure to give a light-yellow oil, which was crystallized in $\mathrm{Et}_{2} \mathrm{O}$ to afford 11a $(2.50 \mathrm{~g}, 61 \%)$ as a white solid. $R_{\mathrm{f}}=0.5$ (hexane/ ethyl acetate, 7:3). ${ }^{1} \mathrm{H}$ NMR $\left(300 \mathrm{MHz}, \mathrm{CDCl}_{3}\right): \delta_{\mathrm{H}}=7.91-7.76$ (m, $4 \mathrm{H}, H \mathrm{pht}), 7.40(\mathrm{~m}, 5 \mathrm{H}, H \mathrm{Ph}), 5.69$ and $5.61(2 \times \mathrm{d}, J=$ $4.0 \mathrm{~Hz}, 2 \times 1 \mathrm{H}, 5-\mathrm{H}, 6-\mathrm{H}), 5.23\left(\mathrm{~s}, 2 \mathrm{H}, \mathrm{CH}_{2} \mathrm{Ph}\right), 4.71(\mathrm{~s}, 1 \mathrm{H}, 2-$ $\mathrm{H}), 1.81\left(\mathrm{~s}, 3 \mathrm{H}, \mathrm{CH}_{3}\right), 1.45$ (s, $\left.3 \mathrm{H}, \mathrm{CH}_{3}\right) \mathrm{ppm} .{ }^{13} \mathrm{C} \mathrm{NMR}(75 \mathrm{MHz}$, $\left.\mathrm{CDCl}_{3}\right): \delta_{\mathrm{C}}=167.9,167.5,166.2,134.4,134.2,131.1,128.4,128.3$, 123.5, 70.5, 67.1, 66.6, 65.7, 58.2, 30.7, 27.5 ppm. HRMS (EI): calcd. for $\mathrm{C}_{23} \mathrm{H}_{20} \mathrm{~N}_{2} \mathrm{O}_{5} \mathrm{SK}[\mathrm{M}+\mathrm{K}]^{+}$475.0729; found 475.0753.

Benzyl (2S,5R,6S)-3,3-Dimethyl-7-oxo-6-phthalimido-4-thia-1-azabicyclo[3.2.0]heptane-2-carboxylate (11b): 1,8-Diazabicyclo[5.4.0]undec-7-ene $(0.05 \mathrm{~mL}, 0.04 \mathrm{mmol})$ was added to a solution of ester 11a $(2.50 \mathrm{~g}, 7.22 \mathrm{mmol})$ in dry DCM $(25 \mathrm{~mL})$ and the mixture was stirred at room temperature for $1 \mathrm{~h}$. The solution was washed with $1 \mathrm{M} \mathrm{NH}_{4} \mathrm{Cl}(\times 2)$, water, and brine. The organic phase was dried $\left(\mathrm{MgSO}_{4}\right)$ and concentrated under vacuum. The residue obtained was purified by chromatography on silica gel using toluene/ethyl acetate $(9.5: 0.5)$ as eluent to give $\mathbf{1 1 b}(2 \mathrm{~g}, 80 \%)$ as a white solid. $R_{\mathrm{f}}=0.4$ (toluene/ethyl acetate, 9.5:0.5). ${ }^{1} \mathrm{H}$ NMR $(300 \mathrm{MHz}$, $\left.\mathrm{CDCl}_{3}\right): \delta_{\mathrm{H}}=7.93-7.77(\mathrm{~m}, 4 \mathrm{H}, H \mathrm{pht}), 7.43-7.37(\mathrm{~m}, 5 \mathrm{H}, \mathrm{HPh})$, 5.59 and $5.42(2 \times \mathrm{d}, J=2.0 \mathrm{~Hz}, 2 \times 1 \mathrm{H}, 5-\mathrm{H}, 6-\mathrm{H}), 5.24(\mathrm{~s}, 2 \mathrm{H}$, $\left.\mathrm{CH}_{2} \mathrm{Ph}\right), 4.68(\mathrm{~s}, 1 \mathrm{H}, 2-\mathrm{H}), 1.65\left(\mathrm{~s}, 3 \mathrm{H}, \mathrm{CH}_{3}\right), 1.44(\mathrm{~s}, 3 \mathrm{H}$, $\left.\mathrm{CH}_{3}\right) \mathrm{ppm} .{ }^{13} \mathrm{C} \mathrm{NMR}\left(75 \mathrm{MHz}, \mathrm{CDCl}_{3}\right): \delta_{\mathrm{C}}=166.8,166.6,166.0$, 134.5, 134.3, 131.2, 128.3, 128.2, 128.1, 123.5, 68.8, 68.7, 67.0, 64.0, 63.9, 34.2, 24.9 ppm. HRMS (EI): calcd. for $\mathrm{C}_{23} \mathrm{H}_{20} \mathrm{~N}_{2} \mathrm{O}_{5} \mathrm{SK}[\mathrm{M}+$ $\mathrm{KJ}^{+}$475.0729; found 475.0737.

Benzyl (2S,5S,6R)-3,3-Dimethyl-7-oxo-6-phthalimido-4-thia-1-azabicyclo[3.2.0|heptane-2-carboxylate (11c): A solution of ester 11a $(2.50 \mathrm{~g}, 5.73 \mathrm{mmol})$ in DCM $(65 \mathrm{~mL})$ and $\mathrm{CCl}_{4}(32 \mathrm{~mL})$ was treated with an equimolar amount of sulfuryl chloride $(0.46 \mathrm{~mL}$, $5.73 \mathrm{mmol}$, solution in $2 \mathrm{~mL}$ of $\mathrm{CCl}_{4}$ ) and stirred at room temperature for $2 \mathrm{~h}$. The solvents were evaporated under reduced pressure to give a mixture of two chlorinated compounds, the trans and cis isomers, in a ratio of around 8:2 as a yellow foam. Major product, the trans isomer: ${ }^{1} \mathrm{H}$ NMR $\left(300 \mathrm{MHz}, \mathrm{CDCl}_{3}\right): \delta_{\mathrm{H}}=7.93-7.79(\mathrm{~m}$, $4 \mathrm{H}, H \mathrm{pht}), 7.47-7.36(\mathrm{~m}, 5 \mathrm{H}, H \mathrm{Ph}), 6.04$ and $5.54(2 \times \mathrm{d}, J=$ $1.5 \mathrm{~Hz}, 2 \times 1 \mathrm{H}, 5-\mathrm{H}, 6-\mathrm{H}), 5.33$ and $5.29(2 \times \mathrm{d}, J=25 \mathrm{~Hz}, 2 \times$ $\left.1 \mathrm{H}, \mathrm{CH}_{2} \mathrm{Ph}\right), 4.65$ (s, $\left.1 \mathrm{H}, 2-\mathrm{H}\right), 1.74$ (s, $\left.3 \mathrm{H}, \mathrm{CH}_{3}\right), 1.72$ (s, $3 \mathrm{H}$,
$\left.\mathrm{CH}_{3}\right) \mathrm{ppm}$. The foam obtained was dissolved in THF $(150 \mathrm{~mL})$ and treated with anhydrous $\mathrm{SnCl}_{2}(1.08 \mathrm{~g}, 5.73 \mathrm{mmol})$. The mixture was stirred at room temperature for $3 \mathrm{~h}$ and then the solvent was evaporated under reduced pressure. The residual oil was dissolved in EtOAc and washed with water $(\times 3)$ and brine. The organic phase was dried $\left(\mathrm{MgSO}_{4}\right)$ and the solvents evaporated under vacuum. The residue obtained was purified by chromatography on silica gel using toluene/ethyl acetate (9.5:0.5) as eluent and afforded the desired isomer 11c ( $2 \mathrm{~g}, 80 \%$ for two steps) as white solids. $R_{\mathrm{f}}=0.3$ (toluene/ethyl acetate, 9.5:0.5). ${ }^{1} \mathrm{H}$ NMR $\left(300 \mathrm{MHz}, \mathrm{CDCl}_{3}\right): \delta_{\mathrm{H}}=$ 7.95-7.85 (m, $4 \mathrm{H}, H$ pht), 7.45-7.34 (m, 5 H, HPh), 5.57 and 5.45 $(2 \times \mathrm{d}, J=2.1 \mathrm{~Hz}, 2 \times 1 \mathrm{H}, 5-\mathrm{H}, 6-\mathrm{H}), 5.27(\mathrm{~d}, J=4.2 \mathrm{~Hz}, 2 \mathrm{H}$, $\left.\mathrm{CH}_{2} \mathrm{Ph}\right), 3.93(\mathrm{~s}, 1 \mathrm{H}, 2-\mathrm{H}), 1.67\left(\mathrm{~s}, 3 \mathrm{H}, \mathrm{CH}_{3}\right), 1.41(\mathrm{~s}, 3 \mathrm{H}$, $\mathrm{CH}_{3}$ ) ppm. ${ }^{13} \mathrm{C}$ NMR $\left(75 \mathrm{MHz}, \mathrm{CDCl}_{3}\right): \delta_{\mathrm{C}}=166.2,166.1,165.3$, 134.5, 134.2, 131.2, 128.5, 128.3, 128.3, 123.5, 69.8, 67.5, 66.0, 65.7, 59.5, 31.0, 24.3 ppm. HRMS (EI): calcd. for $\mathrm{C}_{23} \mathrm{H}_{20} \mathrm{~N}_{2} \mathrm{O}_{5} \mathrm{SK}[\mathrm{M}+$ $\mathrm{K}]^{+}$475.0729; found 475.0708.

Benzyl (2S,5S,6S)-3,3-Dimethyl-7-oxo-6-phthalimido-4-thia-1-azabicyclo[3.2.0]heptane-2-carboxylate (11d): A solution of ester 11b $(0.50 \mathrm{~g}, 1.14 \mathrm{mmol})$ in $\mathrm{DCM}(13 \mathrm{~mL})$ and $\mathrm{CCl}_{4}(6.40 \mathrm{~mL})$ was treated with an equimolar amount of sulfuryl chloride $(92 \mu \mathrm{L}$, $1.14 \mathrm{mmol}$, solution in $1 \mathrm{~mL}$ of $\mathrm{CCl}_{4}$ ) and stirred at room temperature for $1 \mathrm{~h}$. The solvents were evaporated under vacuum to give a mixture of two chlorinated compounds, the trans and cis isomers, in a ratio of around 9:1 as a yellow foam. Major product, the trans isomer: ${ }^{1} \mathrm{H}$ NMR $\left(300 \mathrm{MHz}, \mathrm{CDCl}_{3}\right): \delta_{\mathrm{H}}=7.94-7.78(\mathrm{~m}, 4 \mathrm{H}$, $H$ pht $), 7.44-7.35$ (m, 5H, HPh), 6.12 and $5.49(2 \times \mathrm{d}, J=1.5 \mathrm{~Hz}$, $2 \times 1 \mathrm{H}, 5-\mathrm{H}, 6-\mathrm{H}), 5.30$ and $5.26(2 \times \mathrm{d}, J=20 \mathrm{~Hz}, 2 \times 1 \mathrm{H}$, $\left.\mathrm{CH}_{2} \mathrm{Ph}\right), 4.41(\mathrm{~s}, 1 \mathrm{H}, 2-\mathrm{H}), 1.72\left(\mathrm{~s}, 3 \mathrm{H}, \mathrm{CH}_{3}\right), 1.72(\mathrm{~s}, 3 \mathrm{H}$, $\left.\mathrm{CH}_{3}\right) \mathrm{ppm}$. The foam obtained was dissolved in THF $(26 \mathrm{~mL})$ and treated with anhydrous $\mathrm{SnCl}_{2}(0.21 \mathrm{~g}, 1.14 \mathrm{mmol})$. The mixture was stirred at room temperature for $2 \mathrm{~h}$ and then the solvent was evaporated under reduced pressure. The residual oil was dissolved in EtOAc and washed with water $(\times 3)$ and brine. The organic phase was dried $\left(\mathrm{MgSO}_{4}\right)$ and concentrated under vacuum. The residue obtained was purified by chromatography on silica gel using toluene/ethyl acetate (9.5:0.5) as eluent to give the starting $11 \mathrm{~b}(0.26 \mathrm{~g}$, $52 \%$ for two steps) and the desired isomer 11d $(0.15 \mathrm{~g}, 31 \%$ for two steps) as white solids. $R_{\mathrm{f}}(\mathbf{1 1 d})=0.3$ (toluene/ethyl acetate, 9.5:0.5). ${ }^{1} \mathrm{H}$ NMR $\left(300 \mathrm{MHz}, \mathrm{CDCl}_{3}\right): \delta_{\mathrm{H}}=7.92-7.76(\mathrm{~m}, 4 \mathrm{H}$, $H$ pht), 7.49-7.37 (m, $5 \mathrm{H}, H \mathrm{Ph}), 5.64$ and $5.28(2 \times \mathrm{d}, J=4.0 \mathrm{~Hz}$, $2 \times 1 \mathrm{H}, 5-\mathrm{H}, 6-\mathrm{H}), 5.33\left(\mathrm{~m}, 2 \mathrm{H}, \mathrm{CH}_{2} \mathrm{Ph}\right), 4.03$ (s, $\left.1 \mathrm{H}, 2-\mathrm{H}\right), 1.71$ $\left(\mathrm{s}, 3 \mathrm{H}, \mathrm{CH}_{3}\right), 1.70\left(\mathrm{~s}, 3 \mathrm{H}, \mathrm{CH}_{3}\right) \mathrm{ppm} .{ }^{13} \mathrm{C} \mathrm{NMR}(75 \mathrm{MHz}$, $\left.\mathrm{CDCl}_{3}\right): \delta_{\mathrm{C}}=166.2,164.7,164.4,134.6,134.1,131.2,128.5,128.3$, 123.5, 72.6, 67.4, 64.6, 62.9, 58.7, 29.8, 27.0 ppm. HRMS (EI): calcd. for $\mathrm{C}_{23} \mathrm{H}_{20} \mathrm{~N}_{2} \mathrm{O}_{5} \mathrm{SK}[\mathrm{M}+\mathrm{K}]^{+}$475.0729; found 475.0755.

General Procedure 1. Synthesis of Benzoic Acid Derivatives from the Protected Phthalimide Penicillin (Example: Compound 12a)

2-[(2S,5R,6R)-2-(Benzyloxycarbonyl)-3,3-dimethyl-7-oxo-4-thia-1azabicyclo[3.2.0]heptane-6-ylcarbamoyl]benzoic Acid (12a): Sodium disulfide $(0.27 \mathrm{~g}, 1.14 \mathrm{mmol})$ was added at $0-5{ }^{\circ} \mathrm{C}$ to a solution of the protected phthalimide derivative 11a $(0.50 \mathrm{~g}, 1.14 \mathrm{mmol})$ in a $\mathrm{THF} / \mathrm{H}_{2} \mathrm{O}$ mixture $(13 \mathrm{~mL} / 13 \mathrm{~mL})$. The solution was stirred at 0 $5{ }^{\circ} \mathrm{C}$ for $15 \mathrm{~min}$ and then acidified with citric acid $(0.5 \mathrm{M})$ to $\mathrm{pH} 4$. DCM was added and the aqueous phase was extracted three times with DCM. The organic phases were combined and washed successively with water and brine, dried $\left(\mathrm{MgSO}_{4}\right)$, and concentrated under vacuum. The residue obtained was purified by chromatography on silica gel using DCM/ethyl acetate $(9: 1$ to $8: 2)$ as eluent to give 12a $(0.35 \mathrm{~g}, 67 \%)$ as a white solid. $R_{\mathrm{f}}=0.2(\mathrm{DCM} /$ ethyl acetate, 4:6). ${ }^{1} \mathrm{H}$ NMR $\left(300 \mathrm{MHz}, \mathrm{CDCl}_{3}\right): \delta_{\mathrm{H}}=8.00(\mathrm{~d}, J=$ $7.2 \mathrm{~Hz}, 1 \mathrm{H}, \mathrm{Hph}), 7.62-7.44$ (m, $3 \mathrm{H}, \mathrm{H} p h), 7.44$ (s, $5 \mathrm{H}, \mathrm{Har})$, 
$6.88(\mathrm{~d}, J=8.7 \mathrm{~Hz}, 1 \mathrm{H}, \mathrm{N} H), 5.88(\mathrm{dd}, J=4.0, J=8.7 \mathrm{~Hz}, 1 \mathrm{H}$, 6-H), 5.67 (d, $J=4.0 \mathrm{~Hz}, 1 \mathrm{H}, 5-\mathrm{H}), 5.20$ (s, $\left.2 \mathrm{H}, \mathrm{CH}_{2} \mathrm{Ph}\right), 4.46$ (s, $1 \mathrm{H}, 2-\mathrm{H}), 1.56\left(\mathrm{~s}, 3 \mathrm{H}, \mathrm{CH}_{3}\right), 1.41\left(\mathrm{~s}, 3 \mathrm{H}, \mathrm{CH}_{3}\right) \mathrm{ppm} .{ }^{13} \mathrm{C} \mathrm{NMR}$ $\left(75 \mathrm{MHz}, \mathrm{CDCl}_{3}\right): \delta_{\mathrm{C}}=173.2,169.1,168.9,167.2,136.7,134.4$, $132.4,130.8,129.9,128.4,127.9,127.6,70.2,67.7,67.2,64.5,58.8$, 31.2, $26.6 \mathrm{ppm}$. HRMS (EI): calcd. for $\mathrm{C}_{23} \mathrm{H}_{22} \mathrm{~N}_{2} \mathrm{O}_{6} \mathrm{SNa}$ $[\mathrm{M}+\mathrm{Na}]^{+}$477.1096; found 477.1107.

2-I(2S,5R,6S)-2-(Benzyloxycarbonyl)-3,3-dimethyl-7-oxo-4-thia-1azabicyclo[3.2.0]heptane-6-ylcarbamoyl]benzoic Acid (12b): General procedure 1 was carried out by using compound $11 \mathbf{b}(0.50 \mathrm{~g}$, $1.14 \mathrm{mmol})$ as the starting material. The residue obtained was purified by chromatography on silica gel using DCM/ethyl acetate (10:0 to $9: 1)$ as eluent to give $\mathbf{1 2 b}(0.27 \mathrm{~g}, 51 \%)$ as a white solid. $R_{\mathrm{f}}=$ 0.4 (DCM/MeOH, 9:1). ${ }^{1} \mathrm{H}$ NMR (300 MHz, $\left.\mathrm{CDCl}_{3}\right): \delta_{\mathrm{H}}=8.00$ (d, $J=7.6 \mathrm{~Hz}, 1 \mathrm{H}, \mathrm{H} p h), 7.54-7.49(\mathrm{~m}, 3 \mathrm{H}, \mathrm{Hph}), 7.37-7.29(\mathrm{~m}$, $5 \mathrm{H}, \mathrm{Har}), 5.39(\mathrm{~d}, J=1.4 \mathrm{~Hz}, 1 \mathrm{H}, 5-\mathrm{H}), 5.26(\mathrm{dd}, J=9.0, J=$ $1.4 \mathrm{~Hz}, 1 \mathrm{H}, 6-\mathrm{H}), 5.09$ (s, $\left.2 \mathrm{H}, \mathrm{CH}_{2} \mathrm{Ph}\right), 4.50$ (s, $\left.1 \mathrm{H}, 2-\mathrm{H}\right), 1.57$ $\left(\mathrm{s}, 3 \mathrm{H}, \mathrm{CH}_{3}\right), 1.32\left(\mathrm{~s}, 3 \mathrm{H}, \mathrm{CH}_{3}\right) \mathrm{ppm} \cdot{ }^{13} \mathrm{C} \mathrm{NMR}(75 \mathrm{MHz}$, $\left.\mathrm{CDCl}_{3}\right): \delta_{\mathrm{C}}=172.6,169.2,168.7,167.4,136.5,134.2,132.3,130.7$, $129.8,128.3,128.2,127.7,69.2,68.8,67.3,66.3,63.9,32.8$, $25.4 \mathrm{ppm}$. HRMS (EI): calcd. for $\mathrm{C}_{23} \mathrm{H}_{22} \mathrm{~N}_{2} \mathrm{O}_{6} \mathrm{SNa}[\mathrm{M}+\mathrm{Na}]^{+}$ 477.1096; found 477.1082.

2-I(2S,5S,6R)-2-(Benzyloxycarbonyl)-3,3-dimethyl-7-oxo-4-thia-1azabicyclo[3.2.0|heptane-6-ylcarbamoyl]benzoic Acid (12c): General procedure 1 was carried out by using compound $11 \mathrm{c}(0.50 \mathrm{~g}$, $1.12 \mathrm{mmol}$ ) as the starting material. The residue obtained was purified by chromatography on silica gel using DCM/ethyl acetate $(9: 1$ to $8.5: 1.5)$ as eluent to give $11 \mathrm{c}(0.25 \mathrm{~g}, 48 \%)$ as a white solid. $R_{\mathrm{f}}$ $=0.4(\mathrm{DCM} / \mathrm{MeOH}, 9: 1) .{ }^{1} \mathrm{H}$ NMR $\left(300 \mathrm{MHz}, \mathrm{CDCl}_{3}\right): \delta_{\mathrm{H}}=7.93$ $(\mathrm{d}, J=7.6 \mathrm{~Hz}, 1 \mathrm{H}, \mathrm{Hph}), 7.53-7.44(\mathrm{~m}, 3 \mathrm{H}, \mathrm{Hph}), 7.38-7.34(\mathrm{~m}$, $5 \mathrm{H}, \mathrm{Har}), 5.32$ (d, $J=1.8 \mathrm{~Hz}, 1 \mathrm{H}, 5-\mathrm{H}), 5.17$ (s, $2 \mathrm{H}, \mathrm{CH}_{2} \mathrm{Ph}$ ), $5.10(\mathrm{dd}, J=7.2, J=1.8 \mathrm{~Hz}, 1 \mathrm{H}, 6-\mathrm{H}), 3.79$ (s, $1 \mathrm{H}, 2-\mathrm{H}), 1.60$ $\left(\mathrm{s}, 3 \mathrm{H}, \mathrm{CH}_{3}\right), 1.35\left(\mathrm{~s}, 3 \mathrm{H}, \mathrm{CH}_{3}\right) \mathrm{ppm} .{ }^{13} \mathrm{C} \mathrm{NMR}(75 \mathrm{MHz}$, $\left.\mathrm{CDCl}_{3}\right): \delta_{\mathrm{C}}=170.1,168.6,167.8,166.0,136.1,134.5,132.1,130.7$, $129.9,128.5,128.3,127.9,69.8,67.4,66.7,64.9,63.5,30.5$, 24.7 ppm. HRMS (EI): calcd. for $\mathrm{C}_{23} \mathrm{H}_{22} \mathrm{~N}_{2} \mathrm{O}_{6} \mathrm{SNa}[\mathrm{M}+\mathrm{Na}]^{+}$ 477.1096; found 477.1105.

2-I(2S,5S,6S)-2-(Benzyloxycarbonyl)-3,3-dimethyl-7-oxo-4-thia-1azabicyclo[3.2.0]heptane-6-ylcarbamoyl]benzoic Acid (12d): Sodium disulfide $(0.26 \mathrm{~g}, 1.08 \mathrm{mmol})$ was dissolved in water $(1 \mathrm{~mL})$ and added dropwise to a solution of the protected phthalimide derivative $11 d(0.56 \mathrm{~g}, 1.28 \mathrm{mmol})$ in a $\mathrm{THF} / \mathrm{H}_{2} \mathrm{O}$ mixture $(13 \mathrm{~mL} / 13 \mathrm{~mL})$ at $0-5{ }^{\circ} \mathrm{C}$. The solution was stirred at $0-5{ }^{\circ} \mathrm{C}$ for $15 \mathrm{~min}$ and then acidified with citric acid $(0.5 \mathrm{M})$ to $\mathrm{pH} 4$. DCM was added and the aqueous phase was extracted three times with DCM. The organic phases were combined and washed successively with water and brine, dried $\left(\mathrm{MgSO}_{4}\right)$, and concentrated under vacuum. A mixture of $12 \mathbf{d}$ and the starting phthalimide $11 \mathbf{d}$ in a ratio of 70:30 (0.59 g) was obtained as a yellow foam and used in the next step without further purification. A sample of the compound was purified by chromatography on silica gel using DCM/MeOH (9.8:0.2) as eluent to give 12d as a white solid. $R_{\mathrm{f}}=0.3(\mathrm{DCM} / \mathrm{MeOH}, 9: 1) .{ }^{1} \mathrm{H}$ NMR (300 MHz, $\left.\mathrm{CDCl}_{3}\right): \delta_{\mathrm{H}}=8.03(\mathrm{~d}, J=7.5 \mathrm{~Hz}, 1 \mathrm{H}, \mathrm{H} p h), 7.65-7.50$ (m, $3 \mathrm{H}, \mathrm{H} p h), 7.38-7.21$ (m, $5 \mathrm{H}, \mathrm{Har}), 6.79$ (d, $J=8.5 \mathrm{~Hz}, 1 \mathrm{H}$, $\mathrm{NH}), 5.74(\mathrm{dd}, J=4.0, J=8.5 \mathrm{~Hz}, 1 \mathrm{H}, 6-\mathrm{H}), 5.42(\mathrm{~d}, J=4.0 \mathrm{~Hz}$, $1 \mathrm{H}, 5-\mathrm{H}), 5.20\left(\mathrm{~s}, 2 \mathrm{H}, \mathrm{CH}_{2} \mathrm{Ph}\right), 3.90(\mathrm{~s}, 1 \mathrm{H}, 2-\mathrm{H}), 1.65$ (s, $3 \mathrm{H}$, $\left.\mathrm{CH}_{3}\right), 1.43\left(\mathrm{~s}, 3 \mathrm{H}, \mathrm{CH}_{3}\right) \mathrm{ppm} .{ }^{13} \mathrm{C} \mathrm{NMR}\left(75 \mathrm{MHz}, \mathrm{CDCl}_{3}\right): \delta_{\mathrm{C}}=$ $170.5,169.3,167.5,165.7,135.9,134.2,132.3,131.3,130.2,128.4$, 128.3, 127.7, 127.5, 71.3, 67.6, 65.0, 63.7, 58.2, 30.3, $25.2 \mathrm{ppm}$. HRMS (EI): calcd. for $\mathrm{C}_{23} \mathrm{H}_{22} \mathrm{~N}_{2} \mathrm{O}_{6} \mathrm{SNa}[\mathrm{M}+\mathrm{Na}]^{+} 477.1096$; found 477.1090.
General Procedure 2. Synthesis of the Phthalisoimido Derivative from the Benzoic Acid Derivative (Example: Compound 13a)

Benzyl (2S,5R,6R)-3,3-Dimethyl-7-oxo-6-phthalisoimido-4-thia-1azabicyclo[3.2.0]heptane-2-carboxylate (13a): DCC $(0.12 \mathrm{~g}$, $0.60 \mathrm{mmol})$ was added to a stirred solution of the acid 12a $(0.27 \mathrm{~g}$, $0.60 \mathrm{mmol})$ in dry DCM $(10 \mathrm{~mL})$ at $0{ }^{\circ} \mathrm{C}$. The reaction mixture was stirred for $1 \mathrm{~h}$ at $0{ }^{\circ} \mathrm{C}$ and for an additional $1 \mathrm{~h}$ at room temperature. Then the reaction mixture was again cooled to $0^{\circ} \mathrm{C}$ and the precipitated dicyclohexylurea (DCU) was removed by filtration. The residue obtained was purified by chromatography on silica gel using DCM/ethyl acetate (9:1) as eluent to give 13a $(0.18 \mathrm{~g}, 70 \%)$ as a white foam. $R_{\mathrm{f}}=0.5$ (hexane/ethyl acetate, 7:4). ${ }^{1} \mathrm{H}$ NMR $\left(300 \mathrm{MHz}, \mathrm{CDCl}_{3}\right): \delta_{\mathrm{H}}=8.04(\mathrm{~d}, J=7.4 \mathrm{~Hz}, 1 \mathrm{H}, H \mathrm{pht}), 7.96(\mathrm{~d}$, $J=7.2 \mathrm{~Hz}, 1 \mathrm{H}, H \mathrm{pht}), 7.83$ (td, $J=7.2, J=1.2 \mathrm{~Hz}, 1 \mathrm{H}, H \mathrm{pht})$, $7.76(\mathrm{td}, J=7.4, J=1.2 \mathrm{~Hz}, 1 \mathrm{H}, H \mathrm{pht}), 7.42-7.35(\mathrm{~m}, 5 \mathrm{H}, H \mathrm{Ph})$, 5.71 and $5.63(2 \times \mathrm{d}, J=4.2 \mathrm{~Hz}, 2 \times 1 \mathrm{H}, 6-\mathrm{H}, 5-\mathrm{H}), 5.23(\mathrm{~d}, J=$ $2.1 \mathrm{~Hz}, 2 \mathrm{H}, \mathrm{CH} \mathrm{H}_{2} \mathrm{Ph}$ ), 4.55 (s, $\left.1 \mathrm{H}, 2-\mathrm{H}\right), 1.66$ (s, $\left.3 \mathrm{H}, \mathrm{CH}_{3}\right), 1.43$ (s, $\left.3 \mathrm{H}, \mathrm{CH}_{3}\right) \mathrm{ppm} .{ }^{13} \mathrm{C} \mathrm{NMR}\left(75 \mathrm{MHz}, \mathrm{CDCl}_{3}\right): \delta_{\mathrm{C}}=172.2,167.4$, 163.2, 151.1, 135.4, 135.2, 134.5, 133.1, 128.3, 127.7, 125.1, 123.5, 70.4, 68.0, 67.3, 67.1, 63.3, 30.6, 26.2 ppm. HRMS (EI): calcd. for $\mathrm{C}_{23} \mathrm{H}_{20} \mathrm{~N}_{2} \mathrm{O}_{5} \mathrm{SNa}[\mathrm{M}+\mathrm{Na}]^{+} 459.0990$; found 459.0983 .

Benzyl (2S,5R,6S)-3,3-Dimethyl-7-oxo-6-phthalisoimido-4-thia-1azabicyclo[3.2.0]heptane-2-carboxylate (13b): General procedure 2 was carried out by using compound $\mathbf{1 2 b}(0.14 \mathrm{~g}, 0.32 \mathrm{mmol})$ as the starting material. The residue obtained was purified by chromatography on silica gel using DCM/ethyl acetate $(9: 1)$ as eluent to give 13b $(0.07 \mathrm{~g}, 57 \%)$ as a white foam. $R_{\mathrm{f}}=0.4$ (hexane/ethyl acetate, 7:4). ${ }^{1} \mathrm{H} \mathrm{NMR}\left(300 \mathrm{MHz}, \mathrm{CDCl}_{3}\right): \delta_{\mathrm{H}}=7.98(\mathrm{t}, J=6.5 \mathrm{~Hz}, 2 \mathrm{H}$, $H \mathrm{pht}), 7.84$ (dt, $J=7.2, J=1.2 \mathrm{~Hz}, 1 \mathrm{H}, H \mathrm{pht}), 7.70(\mathrm{dt}, J=7.2$, $J=0.9 \mathrm{~Hz}, 1 \mathrm{H}, H \mathrm{pht}), 7.42-7.36(\mathrm{~m}, 5 \mathrm{H}, H \mathrm{Ph}), 5.53$ and 5.40 $(2 \times \mathrm{d}, J=1.5 \mathrm{~Hz}, 2 \times 1 \mathrm{H}, 5-\mathrm{H}, 6-\mathrm{H}), 5.23(\mathrm{~d}, J=4.8 \mathrm{~Hz}, 2 \mathrm{H}$, $\left.\mathrm{CH}_{2} \mathrm{Ph}\right), 4.62(\mathrm{~s}, 1 \mathrm{H}, 2-\mathrm{H}), 1.66\left(\mathrm{~s}, 3 \mathrm{H}, \mathrm{CH}_{3}\right), 1.44(\mathrm{~s}, 3 \mathrm{H}$, $\left.\mathrm{CH}_{3}\right) \mathrm{ppm} .{ }^{13} \mathrm{C} \mathrm{NMR}\left(75 \mathrm{MHz}, \mathrm{CDCl}_{3}\right): \delta_{\mathrm{C}}=168.3,167.0,163.3$, $151.4,135.5,135.2,134.5,133.1,128.4,128.3,125.2,123.3,74.6$, $69.5,69.3,67.0,64.3,33.2,25.5$ ppm. HRMS (EI): calcd. for $\mathrm{C}_{23} \mathrm{H}_{20} \mathrm{~N}_{2} \mathrm{O}_{5} \mathrm{SNa}[\mathrm{M}+\mathrm{Na}]^{+} 459.0990$; found 459.0998.

Benzyl (2S,5S,6R)-3,3-Dimethyl-7-oxo-6-phthalisoimido-4-thia-1azabicyclo[3.2.0|heptane-2-carboxylate (13c): General procedure 2 was carried out by using compound $12 \mathrm{c}(0.30 \mathrm{~g}, 0.66 \mathrm{mmol})$ as the starting material. The residue obtained was purified by chromatography on silica gel using DCM/ethyl acetate $(9: 1)$ as eluent to give 13c $(0.12 \mathrm{~g}, 45 \%)$ as a white foam. $R_{\mathrm{f}}=0.4$ (hexane/ethyl acetate, 7:4). ${ }^{1} \mathrm{H} \mathrm{NMR}\left(300 \mathrm{MHz}, \mathrm{CDCl}_{3}\right): \delta_{\mathrm{H}}=7.98(\mathrm{t}, J=6.5 \mathrm{~Hz}, 2 \mathrm{H}$, $H \mathrm{pht}), 7.84$ (td, $J=7.2, J=1.2 \mathrm{~Hz}, 1 \mathrm{H}, H \mathrm{pht}), 7.70$ (td, $J=7.2$, $J=0.9 \mathrm{~Hz}, 1 \mathrm{H}, H \mathrm{pht}), 7.42-7.36(\mathrm{~m}, 5 \mathrm{H}, \mathrm{HPh}), 5.53$ and 5.40 $(2 \times \mathrm{d}, J=1.5 \mathrm{~Hz}, 2 \times 1 \mathrm{H}, 5-\mathrm{H}, 6-\mathrm{H}), 5.23(\mathrm{~d}, J=4.8 \mathrm{~Hz}, 2 \mathrm{H}$, $\left.\mathrm{CH}_{2} \mathrm{Ph}\right), 4.62(\mathrm{~s}, 1 \mathrm{H}, 2-\mathrm{H}), 1.66\left(\mathrm{~s}, 3 \mathrm{H}, \mathrm{CH}_{3}\right), 1.44(\mathrm{~s}, 3 \mathrm{H}$, $\left.\mathrm{CH}_{3}\right) \mathrm{ppm} .{ }^{13} \mathrm{C}$ NMR $\left(75 \mathrm{MHz}, \mathrm{CDCl}_{3}\right): \delta_{\mathrm{C}}=166.6,165.8,163.2$, $151.5,135.5,135.2,134.5,133.1,128.6,128.3,128.0,125.2,123.3$, 71.3, 70.4, 67.5, 67.0, 64.8, 30.3, 24.9 ppm. HRMS (EI): calcd. for $\mathrm{C}_{23} \mathrm{H}_{20} \mathrm{~N}_{2} \mathrm{O}_{5} \mathrm{SNa}[\mathrm{M}+\mathrm{Na}]^{+} 459.0990$; found 459.0996.

Benzyl (2S,5S,6S)-3,3-Dimethyl-7-oxo-6-phthalisoimido-4-thia-1azabicyclo[3.2.0]heptane-2-carboxylate (13d): DCC (0.20 g, $0.97 \mathrm{mmol}$ ) was added to a stirred solution of the crude acid $\mathbf{1 2 d}$ $(0.59 \mathrm{~g}$; contaminated by the starting phthalimide $)$ in dry DCM $(25 \mathrm{~mL})$ at $0{ }^{\circ} \mathrm{C}$. The reaction mixture was stirred for $1 \mathrm{~h}$ at $0{ }^{\circ} \mathrm{C}$ and for an additional $1 \mathrm{~h}$ at room temperature. Then the reaction mixture was again cooled to $0{ }^{\circ} \mathrm{C}$ and the precipitated dicyclohexylurea (DCU) was removed by filtration. The filtrate was concentrated and afforded the crude phthalisoimide 13d contaminated by a small proportion of DCU and the starting phthalimide 11d. The yellow foam $(0.56 \mathrm{~g})$ was used in the next step without further puri- 
fication because of the total degradation of the compound on silica gel chromatography. $R_{\mathrm{f}}=0.4$ (DCM/ethyl acetate, 9.8:0.2). Major product 13d: ${ }^{1} \mathrm{H}$ NMR $\left(300 \mathrm{MHz}, \mathrm{CDCl}_{3}\right): \delta_{\mathrm{H}}=8.04(\mathrm{~d}, J=$ $7.5 \mathrm{~Hz}, 1 \mathrm{H}, H \mathrm{pht}), 7.95$ (d, $J=7.5 \mathrm{~Hz}, 1 \mathrm{H}, H \mathrm{pht}), 7.85-7.73$ (m, $2 \mathrm{H}, H \mathrm{pht}), 7.44-7.34(\mathrm{~m}, 5 \mathrm{H}, H \mathrm{Ph}), 5.52$ and $5.46(2 \times \mathrm{d}, J=$ $4.1 \mathrm{~Hz}, 2 \times 1 \mathrm{H}, 6-\mathrm{H}, 5-\mathrm{H}), 5.27$ (s, $\left.2 \mathrm{H}, \mathrm{CH}_{2} \mathrm{Ph}\right), 3.91$ (s, $1 \mathrm{H}, 2-$ $\mathrm{H}), 1.64$ (s, $3 \mathrm{H}, \mathrm{CH}_{3}$ ), 1.54 (s, $3 \mathrm{H}, \mathrm{CH}_{3}$ ) ppm. HRMS (EI): calcd. for $\mathrm{C}_{23} \mathrm{H}_{20} \mathrm{~N}_{2} \mathrm{O}_{5} \mathrm{SNa}[\mathrm{M}+\mathrm{Na}]^{+}$459.0990; found 459.0985.

\section{General Procedure 3. Deprotection of the Phthalisoimide Group (Ex-} ample: Compound 14a)

Benzyl (2S,5R,6R)-6-Amino-3,3-dimethyl-7-oxo-4-thia-1-azabicyclo[3.2.0]heptane-2-carboxylate (14a): The phthalisoimide 13a $(0.17 \mathrm{~g}, 0.38 \mathrm{mmol})$ was dissolved in dry THF $(8.50 \mathrm{~mL})$ and the solution was cooled to $-20^{\circ} \mathrm{C}$. A 2 M solution of $N$-methylhydrazine $(0.19 \mathrm{~mL}, 0.38 \mathrm{mmol})$ in THF was added dropwise and the reaction mixture was stirred for $20 \mathrm{~min}$ at $-20^{\circ} \mathrm{C}$. The solvent was evaporated under reduced pressure and the residue obtained was co-evaporated several times with chloroform until precipitation of the byproduct hydrazide. The byproduct was removed by filtration, and the filtrate was concentrated to afford the crude amine 14a (0.12 mg, quant.) as a white amorphous solid. No further purification was necessary. $R_{\mathrm{f}}=0.4$ (DCM/ethyl acetate, $\left.6: 4\right)$. $[\alpha]_{\mathrm{D}}^{20}=-0.17$ $\left(c=4\right.$, chloroform). ${ }^{1} \mathrm{H}$ NMR $\left(300 \mathrm{MHz}, \mathrm{CDCl}_{3}\right): \delta_{\mathrm{H}}=7.39(\mathrm{~s}, 5$ $\mathrm{H}, H \mathrm{Ph}), 5.53$ and $4.58(2 \times \mathrm{d}, J=4.2 \mathrm{~Hz}, 2 \times 1 \mathrm{H}, 6-\mathrm{H}, 5-\mathrm{H})$, 5.20 (s, $\left.2 \mathrm{H}, \mathrm{CH}_{2} \mathrm{Ph}\right), 4.44$ (s, $\left.1 \mathrm{H}, 2-\mathrm{H}\right), 1.63$ (s, $\left.3 \mathrm{H}, \mathrm{CH}_{3}\right), 1.44$ (s, $3 \mathrm{H}, \mathrm{CH}_{3}$ ) ppm. ${ }^{13} \mathrm{C} \mathrm{NMR}\left(75 \mathrm{MHz}, \mathrm{CDCl}_{3}\right): \delta_{\mathrm{C}}=177.4,167.6$, $134.5,128.3,69.7,69.6,67.0,63.6,62.5,31.4,26.7$ ppm. HRMS (EI): calcd. for $\mathrm{C}_{15} \mathrm{H}_{18} \mathrm{~N}_{2} \mathrm{O}_{3} \mathrm{SNa}[\mathrm{M}+\mathrm{Na}]^{+}$329.0936; found 329.0932 .

Benzyl (2S,5R,6S)-6-Amino-3,3-dimethyl-7-oxo-4-thia-1-azabicyclo[3.2.0|heptane-2-carboxylate (14b): General procedure 3 was applied to the phthalisoimide $\mathbf{1 3 b}(70 \mathrm{mg}, 0.16 \mathrm{mmol})$ and afforded the amine 14b (49 mg, quant.) as a white solid. $R_{\mathrm{f}}=0.3$ (DCM/ ethyl acetate, 6:4). $[\alpha]_{\mathrm{D}}^{20}=+0.22\left(c=2.2\right.$, chloroform). ${ }^{1} \mathrm{H}$ NMR (300 MHz, $\left.\mathrm{CDCl}_{3}\right): \delta_{\mathrm{H}}=7.37(\mathrm{~s}, 5 \mathrm{H}, H \mathrm{Ph}), 5.19\left(\mathrm{~s}, 2 \mathrm{H}, \mathrm{CH}_{2} \mathrm{Ph}\right)$, 5.11 and $4.23(2 \times \mathrm{d}, J=1.4 \mathrm{~Hz}, 2 \times 1 \mathrm{H}, 5-\mathrm{H}, 6-\mathrm{H}), 4.50(\mathrm{~s}, 1 \mathrm{H}, 2-$ $\mathrm{H}), 1.56\left(\mathrm{~s}, 3 \mathrm{H}, \mathrm{CH}_{3}\right), 1.39$ (s, $\left.3 \mathrm{H}, \mathrm{CH}_{3}\right) \mathrm{ppm} .{ }^{13} \mathrm{C} \mathrm{NMR}(75 \mathrm{MHz}$, $\left.\mathrm{CDCl}_{3}\right): \delta_{\mathrm{C}}=172.8,167.3,134.5,128.3,71.6,71.1,68.2,67.4,64.1$, 33.0, 25.6 ppm. HRMS (EI): calcd. for $\mathrm{C}_{15} \mathrm{H}_{19} \mathrm{~N}_{2} \mathrm{O}_{3} \mathrm{~S}[\mathrm{M}+\mathrm{H}]^{+}$ 307.1116; found 307.1100 .

Benzyl (2S,5S,6R)-6-Amino-3,3-dimethyl-7-oxo-4-thia-1-azabicyclo[3.2.0|heptane-2-carboxylate (14c): General procedure 3 was applied to the phthalisoimide $12 \mathrm{c}(0.12 \mathrm{~g}, 0.27 \mathrm{mmol})$ and afforded the amine $14 \mathrm{c}(80 \mathrm{mg}, 94 \%)$ as a white solid. $R_{\mathrm{f}}=0.3(\mathrm{DCM} / \mathrm{ethyl}$ acetate, 6:4). $[\alpha]_{\mathrm{D}}^{20}=-0.09\left(c=3\right.$, chloroform). ${ }^{1} \mathrm{H}$ NMR $(300 \mathrm{MHz}$, $\left.\mathrm{CDCl}_{3}\right): \delta_{\mathrm{H}}=7.39-7.35(\mathrm{~m}, 5 \mathrm{H}, H \mathrm{Ph}), 5.22(\mathrm{~d}, J=1.5 \mathrm{~Hz}, 2 \mathrm{H}$, $\left.\mathrm{CH}_{2} \mathrm{Ph}\right), 4.87$ and $4.43(2 \times \mathrm{d}, J=1.7 \mathrm{~Hz}, 2 \times 1 \mathrm{H}, 5-\mathrm{H}, 6-\mathrm{H}), 3.76$ (s, $1 \mathrm{H}, 2-\mathrm{H}), 1.60$ (s, $\left.3 \mathrm{H}, \mathrm{CH}_{3}\right), 1.37$ (s, $\left.3 \mathrm{H}, \mathrm{CH}_{3}\right) \mathrm{ppm} .{ }^{13} \mathrm{C} \mathrm{NMR}$ $\left(75 \mathrm{MHz} \mathrm{CDCl}_{3}\right): \delta_{\mathrm{C}}=171.5,166.2,134.5,128.3,69.7,69.6,67.5$, 67.3, 64.7, 30.4, 24.7 ppm. HRMS (EI): calcd. for $\mathrm{C}_{15} \mathrm{H}_{19} \mathrm{~N}_{2} \mathrm{O}_{3} \mathrm{~S}$ $[\mathrm{M}+\mathrm{H}]^{+}$307.1116; found 307.1095.

Benzyl (2S,5S,6S)-6-Amino-3,3-dimethyl-7-oxo-4-thia-1-azabicyclo[3.2.0]heptane-2-carboxylate (14d): The crude phthalisoimide 13d $(0.56 \mathrm{~g})$ was dissolved in dry THF $(27 \mathrm{~mL})$ and the solution was cooled to $-20{ }^{\circ} \mathrm{C}$. A $2 \mathrm{~m}$ solution of $N$-methylhydrazine $(0.51 \mathrm{~mL}, 1.02 \mathrm{mmol})$ in THF was added dropwise and the reaction mixture was stirred for $20 \mathrm{~min}$ at $-20{ }^{\circ} \mathrm{C}$. The solvent was evaporated under reduced pressure and the residue obtained was co-evaporated several times with chloroform until the precipitation of the byproduct hydrazide. The byproduct was removed by filtration and the filtrate was concentrated under vacuum. The residue obtained was purified by chromatography on silica gel using DCM/ethyl acetate $(9: 1)$ as eluent to give $\mathbf{1 4 d}(0.07 \mathrm{~g}, 18 \%$ for three steps $)$ as a white solid. $R_{\mathrm{f}}=0.4(\mathrm{DCM} / \mathrm{ethyl}$ acetate, $6: 4)$. $[\alpha]_{\mathrm{D}}^{20}=+0.10(c=$ 3.5, chloroform). ${ }^{1} \mathrm{H} \mathrm{NMR}\left(300 \mathrm{MHz}, \mathrm{CDCl}_{3}\right): \delta_{\mathrm{H}}=7.39-7.30(\mathrm{~m}$, $5 \mathrm{H}, H \mathrm{Ph}), 5.25-5.23\left(\mathrm{~m}, 3 \mathrm{H}, 6-\mathrm{H}, \mathrm{CH}_{2} \mathrm{Ph}\right), 4.41$ (dd, $J=0.9, J$ $=4.2 \mathrm{~Hz}, 1 \mathrm{H}, 5-\mathrm{H}), 3.85(\mathrm{~s}, 1 \mathrm{H}, 2-\mathrm{H}), 1.67(\mathrm{~s}, 3 \mathrm{H}, \mathrm{CH}), 1.48(\mathrm{~s}$, $\left.3 \mathrm{H}, \mathrm{CH}_{3}\right) \mathrm{ppm} .{ }^{13} \mathrm{C} \mathrm{NMR}\left(75 \mathrm{MHz}, \mathrm{CDCl}_{3}\right): \delta_{\mathrm{C}}=175.2,165.6$, 134.5, 128.3, 70.6, 67.3, 66.1, 62.4, 61.8, 29.8, 26.0 ppm. HRMS (EI): calcd. for $\mathrm{C}_{15} \mathrm{H}_{19} \mathrm{~N}_{2} \mathrm{O}_{3} \mathrm{~S}[\mathrm{M}+\mathrm{H}]^{+}$307.1116; found 307.1114 .

Benzyl $(2 S, 5 R, 6 R)-6-[(N$-Decanoyl-L-prolyl-L-threonyl-L-alanyl-Lasparaginyl)amino]-3,3-dimethyl-7-oxo-4-thia-1-azabicyclo[3.2.0]heptane-2-carboxylate (2a): Decanoyl-PTAN-COOH (4; $25 \mathrm{mg}$, $0.04 \mathrm{mmol})$ and the amine 14a $(15 \mathrm{mg}, 0.04 \mathrm{mmol})$ were dissolved in dry DMF $(3 \mathrm{~mL})$ and the solution was cooled to $0{ }^{\circ} \mathrm{C}$. $\mathrm{HOBt}$ $(9.10 \mathrm{mg}, 0.06 \mathrm{mmol})$ and EDCI $(17 \mathrm{mg}, 0.08 \mathrm{mmol})$ were added to the solution and the reaction mixture was stirred at room temperature for $6 \mathrm{~h}$. The solvent was then evaporated to dryness under vacuum. The residue obtained was dissolved in DCM and washed successively with water, saturated $\mathrm{NaHCO}_{3}$ solution, and brine. The aqueous phases were extracted several times with DCM and the resulting organic phases were combined, dried, and concentrated under vacuum. The residue obtained was purified by chromatography on silica gel using $\mathrm{DCM} / i \operatorname{PrOH}(9: 1$ to $8: 2)$ as eluent to give $2 \mathrm{a}(8 \mathrm{mg}, 20 \%)$ as a white solid. $R_{\mathrm{f}}=0.3(\mathrm{DCM} /$ $\mathrm{MeOH}, 9: 1) .{ }^{1} \mathrm{H}$ NMR $\left(600 \mathrm{MHz}, \mathrm{CDCl}_{3} / \mathrm{CD}_{3} \mathrm{OD}\right): \delta_{\mathrm{H}}=7.93$, 7.80, 7.50, 6.28, $5.71(5 \times$ br., $5 \times 1 \mathrm{H}, 4 \mathrm{NH}, \mathrm{OH}), 7.37(\mathrm{~m}, 5 \mathrm{H}$, $H \mathrm{Ph}), 5.55(\mathrm{dd}, J=4.2, J=8.4 \mathrm{~Hz}, 1 \mathrm{H}, 6-\mathrm{H}), 5.52(\mathrm{~d}, J=4.2 \mathrm{~Hz}$, $1 \mathrm{H}, 5-\mathrm{H}), 5.18\left(\mathrm{~d}, J=2.4 \mathrm{~Hz}, 2 \mathrm{H}, \mathrm{CH}_{2} \mathrm{Ph}\right), 4.78[\mathrm{~m}, 1 \mathrm{H}$, $H \alpha($ Asn )], 4.46 (s, 1 H, 2-H), 4.46-4.31 [m, 4 H, Ha(Ala, Pro, Thr), $H \beta(\mathrm{Thr})], 3.62,3.53\left[\mathrm{~m}, 2 \mathrm{H}, \mathrm{CH}_{2} \delta\right.$ (Pro)], $2.83[\mathrm{dd}, J=15, J=$ $5.4 \mathrm{~Hz}, 1 \mathrm{H}, \mathrm{CH}_{2 \mathrm{a}} \beta(\mathrm{Asn})$ ], $2.67[\mathrm{dd}, J=15, J=6 \mathrm{~Hz}, 1 \mathrm{H}$, $\mathrm{CH}_{2 \mathrm{~b}} \beta(\mathrm{Asn})$ ], 2.36-2.29 [m, $2 \mathrm{H}, \mathrm{CH}_{2} \beta$ (Pro)], 2.22-2.01 [m, $4 \mathrm{H}$, $\mathrm{CH}_{2} \gamma($ Pro $\left.), \mathrm{CH}_{2 \text { deca }}\right], 1.62$ (s, $\left.3 \mathrm{H}, \mathrm{CH}_{3}\right), 1.60$ (m, $2 \mathrm{H}, \mathrm{CH}_{2 \text { deca }}$ ), $1.46\left[\mathrm{~d}, J=7.2 \mathrm{~Hz}, 3 \mathrm{H}, \mathrm{CH}_{3}\right.$ (Ala)], 1.39 (s, $\left.3 \mathrm{H}, \mathrm{CH}_{3}\right), 1.27-1.25$ $\left(\mathrm{m}, 12 \mathrm{H}, 6 \mathrm{CH}_{2 \mathrm{dec}}\right), 1.16$ [d, $\left.J=6.6 \mathrm{~Hz}, 3 \mathrm{H}, \mathrm{CH}_{3}(\mathrm{Thr})\right], 0.87$ (t, $\left.J=7.2 \mathrm{~Hz}, 3 \mathrm{H}, \mathrm{C} H_{3 \text { deca }}\right)$ ppm. ${ }^{13} \mathrm{C} \mathrm{NMR}\left(75 \mathrm{MHz}, \mathrm{CDCl}_{3} /\right.$ $\left.\mathrm{CD}_{3} \mathrm{OD}\right): \delta_{\mathrm{C}}=173.7,172.9,172.7,172.5,172.2,170.5,170.2,167.3$, 134.4, 128.3, 70.1, 67.5, 67.1, 66.2, 64.3, 60.5, 58.9, 58.1, 49.7, 49.6, 47.4, 36.1, 34.4, 31.5, 31.4, 29.1, 29.0, 28.9, 28.6, 26.5, 24.8, 24.4, $22.3,19.1,16.6,13.7$ p pm. HRMS (EI): calcd. for $\mathrm{C}_{41} \mathrm{H}_{61} \mathrm{~N}_{7} \mathrm{O}_{10} \mathrm{SNa}[\mathrm{M}+\mathrm{Na}]^{+}$866.4098; found 866.4114.

$(2 S, 5 R, 6 R)-6-[(N$-Decanoyl-L-prolyl-L-threonyl-L-alanyl-L-asparaginyl)amino]-3,3-dimethyl-7-oxo-4-thia-1-azabicyclo[3.2.0]heptane2-carboxylic Acid (2'a): Decanoyl-PTAN-COOH (4; 40 mg, $0.07 \mathrm{mmol})$ and the free amine, $N$-( $p$-nitrobenzyloxycarbonyl)-6aminopimelic acid ${ }^{[1]}(55 \mathrm{mg}, 0.15 \mathrm{mmol})$, were dissolved in dry DMF $(4 \mathrm{~mL})$ and the solution was cooled to $0{ }^{\circ} \mathrm{C}$. HOBt $(14 \mathrm{mg}$, $0.10 \mathrm{mmol})$ and EDCI $(27 \mathrm{mg}, 0.14 \mathrm{mmol})$ were added to the solution and the reaction mixture was stirred at room temperature for $6 \mathrm{~h}$. The solvent was then evaporated to dryness under vacuum. The residue obtained was dissolved in DCM and washed with water. The aqueous phase was extracted several times with DCM and the resulting organic phases were combined, dried, and concentrated under vacuum. The residue obtained was dissolved in a mixture of THF/dioxane $(9: 1,3 \mathrm{~mL})$ and hydrogenated under atmospheric pressure on $10 \%$ palladium on carbon $(25 \mathrm{mg})$ for $3 \mathrm{~h}$. The catalyst was filtered and washed with $\mathrm{MeOH}$. The filtrate was concentrated under reduced pressure and purified by reversedphase semi-prep. HPLC $\left(\mathrm{H}_{2} \mathrm{O}\right.$ to $\left.\mathrm{CH}_{3} \mathrm{CN}\right)$ to give $\mathbf{2}^{\prime} \mathbf{a}(7 \mathrm{mg}, 13 \%)$ as a white solid. ${ }^{1} \mathrm{H}$ NMR $\left(300 \mathrm{MHz}, \mathrm{D}_{2} \mathrm{O}\right): \delta_{\mathrm{H}}=5.72-5.62(\mathrm{~m}, 2$

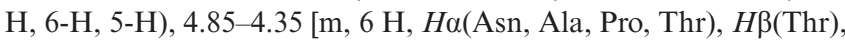
2-H], 3.85-3.71 [m, $2 \mathrm{H}, \mathrm{CH}_{2} \delta$ (Pro)], 3.05-2.83 [m, $2 \mathrm{H}$, $\mathrm{CH}_{2} \beta\left(\right.$ Asn)], 2.60-2.15 [m, $4 \mathrm{H}, \mathrm{CH}_{2} \beta$ (Pro), $\mathrm{CH}_{2} \gamma($ Pro)], 2.17 (m, $3 \mathrm{H}, \mathrm{CH}_{2 \text { deca }}$ ), 1.79 (s, $3 \mathrm{H}, \mathrm{CH}_{3}$ ), 1.75 (m, $2 \mathrm{H}, \mathrm{CH}_{2 \text { deca }}$ ), 1.69 (s, 
$\left.3 \mathrm{H}, \mathrm{CH}_{3}\right), 1.56\left[\mathrm{~m}, 3 \mathrm{H}, \mathrm{CH}_{3}\right.$ (Ala)], 1.55-1.40(m, $12 \mathrm{H}, 6$ $\left.\mathrm{CH}_{2 \text { deca }}\right), 1.37$ [m, $\left.3 \mathrm{H}, \mathrm{CH}_{3}(\mathrm{Thr})\right], 1.07$ (m, $\left.3 \mathrm{H}, \mathrm{C} H_{3 \text { deca }}\right) \mathrm{ppm}$. ${ }^{13} \mathrm{C}$ NMR $\left(75 \mathrm{MHz}, \mathrm{D}_{2} \mathrm{O}\right): \delta_{\mathrm{C}}=176.5,175.8,175.3,175.2,175.1$, 172.8, 172.4, 171. 3, 74.0, 67.9, 67.7, 65.6, 61.7, 59.6, 59.1, 51.2, $50.8,49.1,37.3,35.3,32.5,31.9,30.7,29.8,27.7,25.6,25.5,23.4$, 20.1, 18.0, 14.6 ppm. HRMS (EI): calcd. for $\mathrm{C}_{34} \mathrm{H}_{55} \mathrm{~N}_{7} \mathrm{O}_{10} \mathrm{SNa}[\mathrm{M}$ $+\mathrm{Na}]^{+} 776.3628$; found 776.3614 .

Benzyl $(2 S, 5 R, 6 S)-6-[(N$-Decanoyl-L-prolyl-L-threonyl-L-alanyl-Lasparaginyl)amino]-3,3-dimethyl-7-oxo-4-thia-1-azabicyclo[3.2.0]heptane-2-carboxylate (2b): Decanoyl-PTAN-COOH (4; $20 \mathrm{mg}$, $0.03 \mathrm{mmol})$ and the amine $14 \mathrm{~b}(16.50 \mathrm{mg}, 0.05 \mathrm{mmol})$ were dissolved in dry DMF $(1.5 \mathrm{~mL})$ and the solution was cooled to $0{ }^{\circ} \mathrm{C}$. HOBt ( $7.20 \mathrm{mg}, 0.05 \mathrm{mmol})$ and EDCI (13.80 mg, $0.06 \mathrm{mmol})$ were added to the solution and the reaction mixture was stirred at room temperature for $6 \mathrm{~h}$. The solvent was then evaporated to dryness under vacuum. The residue obtained was dissolved in DCM and washed successively with citric acid solution $(1 \%)$, water, saturated $\mathrm{NaHCO}_{3}$ solution, and brine. The aqueous phases were extracted several times with DCM and the resulting organic phases were combined, dried, and concentrated under vacuum. The residue obtained was purified by chromatography on silica gel using DCM/ $\mathrm{MeOH}(9.5: 0.5$ to $9: 1)$ as eluent to give $2 \mathbf{b}(14 \mathrm{mg}, 46 \%)$ as a white solid. $R_{\mathrm{f}}=0.4(\mathrm{DCM} / \mathrm{MeOH}, 9: 1) .{ }^{1} \mathrm{H} \mathrm{NMR}\left(300 \mathrm{MHz}, \mathrm{CDCl}_{3} /\right.$ $\left.\mathrm{CD}_{3} \mathrm{OD}\right): \delta_{\mathrm{H}}=8.28,7.87,7.82,6.75,6.24(5 \times$ br., $5 \times 1 \mathrm{H}, 4 \mathrm{NH}$, $\mathrm{OH}), 7.37(\mathrm{~m}, 5 \mathrm{H}, H \mathrm{Ph}), 5.28(\mathrm{~d}, J=1.2 \mathrm{~Hz}, 1 \mathrm{H}, 5-\mathrm{H}), 5.18(\mathrm{~s}$, $2 \mathrm{H}, \mathrm{CH}_{2} \mathrm{Ph}$ ), 5.02 (dd, $\left.J=1.2, J=7.8 \mathrm{~Hz}, 1 \mathrm{H}, 6-\mathrm{H}\right), 4.83[\mathrm{~m}, 1$ $\mathrm{H}, H \alpha(\mathrm{Asn})$ ], 4.51 (s, $1 \mathrm{H}, 2-\mathrm{H}), 4.51-4.27$ [m, $4 \mathrm{H}, H \alpha$ (Ala, Pro, Thr), $H \beta(\mathrm{Thr})$ ], 3.69, 3.52 [m, $2 \mathrm{H}, \mathrm{CH}_{2} \delta$ (Pro)], 2.87 [dd, $J=15.5$, $J=6.6 \mathrm{~Hz}, 1 \mathrm{H}, \mathrm{CH}_{2 \mathrm{a}} \beta($ Asn $\left.)\right], 2.70[\mathrm{dd}, J=15.5, J=5.1 \mathrm{~Hz}, 1 \mathrm{H}$, $\mathrm{CH}_{2 \mathrm{~b}} \beta($ Asn $)$, 2.38-2.29 [m, $2 \mathrm{H}, \mathrm{CH}_{2} \beta($ Pro $)$ ], 2.25-1.97 [m, $4 \mathrm{H}$, $\mathrm{CH}_{2} \gamma($ Pro $\left.), \mathrm{CH}_{2 \text { deca }}\right], 1.61$ (m, $\left.2 \mathrm{H}, \mathrm{CH}_{2 \text { deca }}\right), 1.56\left(\mathrm{~s}, 3 \mathrm{H}, \mathrm{CH}_{3}\right)$, $1.44\left[\mathrm{~d}, J=7.3 \mathrm{~Hz}, 3 \mathrm{H}, \mathrm{CH}_{3}\right.$ (Ala)], $1.36\left(\mathrm{~s}, 3 \mathrm{H}, \mathrm{CH}_{3}\right), 1.31-1.25$ $\left(\mathrm{m}, 12 \mathrm{H}, 6 \mathrm{CH}_{2 \text { deca }}\right), 1.17$ [d, $\left.J=6.3 \mathrm{~Hz}, 3 \mathrm{H}, \mathrm{CH}_{3}(\mathrm{Thr})\right], 0.88$ (t, $\left.J=6.9 \mathrm{~Hz}, 3 \mathrm{H}, \mathrm{CH}_{3 \mathrm{deca}}\right) \mathrm{ppm} .{ }^{13} \mathrm{C} \mathrm{NMR}\left(75 \mathrm{MHz}, \mathrm{CDCl}_{3} /\right.$ $\left.\mathrm{CD}_{3} \mathrm{OD}\right): \delta_{\mathrm{C}}=173.3,173.1,172.8,172.4,171.6,170.8,169.6,167.1$, $134.5,128.3,69.4,68.8,67.0,66.7,66.2,63.7,60.4,58.2,50.5,49.7$, $47.4,36.3,34.4,33.0,31.5,29.3,29.2,29.1,28.9,25.4,24.7,24.4$, $22.3,19.3,16.4,13.8$ p pm. HRMS (EI): calcd. for $\mathrm{C}_{41} \mathrm{H}_{61} \mathrm{~N}_{7} \mathrm{O}_{10} \mathrm{SNa}[\mathrm{M}+\mathrm{Na}]^{+}$866.4098; found 866.4094.

Benzyl (2S,5S,6R)-6-I( $N$-Decanoyl-L-prolyl-L-threonyl-L-alanyl-Lasparaginyl)amino]-3,3-dimethyl-7-oxo-4-thia-1-azabicyclo[3.2.0]heptane-2-carboxylate (2c): Decanoyl-PTAN-COOH (4; $25 \mathrm{mg}$, $0.04 \mathrm{mmol})$ and the amine $14 \mathrm{c}(27 \mathrm{mg}, 0.09 \mathrm{mmol})$ were dissolved in dry DMF $(2 \mathrm{~mL})$ and the solution was cooled to $0{ }^{\circ} \mathrm{C}$. HOBt (9.1 $\mathrm{mg}, 0.07 \mathrm{mmol})$ and EDCI $(17 \mathrm{mg}, 0.09 \mathrm{mmol})$ were added to the solution and the reaction was stirred at room temperature for $6 \mathrm{~h}$. The solvent was then evaporated to dryness under vacuum. The residue obtained was dissolved in DCM and washed successively with citric acid solution ( $1 \%$ ), water, saturated $\mathrm{NaHCO}_{3}$ solution, and brine. The aqueous phases were extracted several times with DCM and the resulting organic phases were combined, dried, and concentrated under vacuum. The residue obtained was purified by chromatography on silica gel using DCM/MeOH (9.5:0.5 to 9:1) as eluent to give $2 \mathrm{c}(30 \mathrm{mg}, 70 \%)$ as a white solid. $R_{\mathrm{f}}=0.3(\mathrm{DCM} /$ $\mathrm{MeOH}, 9: 1) .{ }^{1} \mathrm{H}$ NMR $\left(300 \mathrm{MHz}, \mathrm{CDCl}_{3} / \mathrm{CD}_{3} \mathrm{OD}\right): \delta_{\mathrm{H}}=8.19$, $7.90,7.83,6.83,5.91(5 \times$ br., $5 \times 1 \mathrm{H}, 4 \mathrm{NH}, \mathrm{OH}), 7.37-7.33(\mathrm{~m}$, $5 \mathrm{H}, \mathrm{HPh}), 5.18\left(\mathrm{~m}, 3 \mathrm{H}, 5-\mathrm{H}, \mathrm{CH}_{2} \mathrm{Ph}\right), 4.84(\mathrm{~d}, J=2.1 \mathrm{~Hz}, 1 \mathrm{H}$, 6-H), 4.72 [m, $1 \mathrm{H}, H \alpha($ Asn $)], 4.43-4.23$ [m, 4 H, $H \alpha($ Ala, Pro, Thr), $H \beta(\mathrm{Thr})], 3.80$ (s, $1 \mathrm{H}, 2-\mathrm{H}), 3.66,3.52$ [m, $2 \mathrm{H}, \mathrm{CH}_{2} \delta($ Pro)], $2.78\left[\mathrm{dd}, J=15.0, J=6.3 \mathrm{~Hz}, 1 \mathrm{H}, \mathrm{CH}_{2 \mathrm{a}} \beta(\right.$ Asn) $], 2.69[\mathrm{dd}, J=$ $15.0, J=5.4 \mathrm{~Hz}, 1 \mathrm{H}, \mathrm{CH}_{2 \mathrm{~b}} \beta\left(\right.$ Asn)], 2.38-2.27 [m, $2 \mathrm{H}, \mathrm{CH}_{2} \beta$ (Pro)], 2.20-1.90 [m, $4 \mathrm{H}, \mathrm{CH}_{2} \gamma\left(\right.$ Pro), $\left.\mathrm{CH}_{2 \text { deca }}\right], 1.59$ (s, $3 \mathrm{H}, \mathrm{CH}_{3}$ ), 1.58 $\left(\mathrm{m}, 2 \mathrm{H}, \mathrm{C} H_{2 \text { deca }}\right), 1.43\left[\mathrm{~d}, J=7.5 \mathrm{~Hz}, 3 \mathrm{H}, \mathrm{CH}_{3}(\mathrm{Ala})\right], 1.33$ (s, 3
$\left.\mathrm{H}, \mathrm{CH}_{3}\right), 1.27-1.24\left(\mathrm{~m}, 12 \mathrm{H}, 6 \mathrm{CH}_{2 \text { deca }}\right), 1.17[\mathrm{~d}, J=6.3 \mathrm{~Hz}, 3$ $\left.\mathrm{H}, \mathrm{CH}_{3}(\mathrm{Thr})\right], 0.84$ (t, $J=7.2 \mathrm{~Hz}, 3 \mathrm{H}, \mathrm{CH}_{3 \text { deca }}$ ) ppm. ${ }^{13} \mathrm{C} \mathrm{NMR}$ $\left(75 \mathrm{MHz}, \mathrm{CDCl}_{3} / \mathrm{CD}_{3} \mathrm{OD}\right): \delta_{\mathrm{C}}=173.8,173.0,172.9,172.3,171.4$, $171.1,167.9,166.2,134.5,128.4,69.6,67.3,67.0,66.3,65.1,62.8$, $60.5,58.3,49.8,49.5,47.4,36.7,34.3,31.4,30.7,29.6,29.3,29.1$, 29.0, 28.8, 24.6, 24.3, 22.3, 19.2, 16.1, 13.7 ppm. HRMS (EI): calcd. for $\mathrm{C}_{41} \mathrm{H}_{61} \mathrm{~N}_{7} \mathrm{O}_{10} \mathrm{SNa}[\mathrm{M}+\mathrm{Na}]^{+}$866.4098; found 866.4103.

Benzyl (2S,5S,6S)-6-I( $N$-Decanoyl-L-prolyl-L-threonyl-L-alanyl-Lasparaginyl)amino]-3,3-dimethyl-7-oxo-4-thia-1-azabicyclo[3.2.0]heptane-2-carboxylate (2d): Decanoyl-PTAN-COOH (4; $18 \mathrm{mg}$, $0.03 \mathrm{mmol})$ and the amine $\mathbf{1 4 d}(15 \mathrm{mg}, 0.05 \mathrm{mmol})$ were dissolved in dry DMF $(4 \mathrm{~mL})$ and the solution was cooled to $0{ }^{\circ} \mathrm{C}$. $\mathrm{HOBt}$ $(6.5 \mathrm{mg}, 0.05 \mathrm{mmol})$ and EDCI $(12.4 \mathrm{mg}, 0.06 \mathrm{mmol})$ were added to the solution and the reaction mixture was stirred at room temperature for $6 \mathrm{~h}$. The solvent was then evaporated to dryness under vacuum. The residue obtained was dissolved in DCM and washed successively with water, saturated $\mathrm{NaHCO}_{3}$ solution, and brine. The aqueous phases were extracted several times with DCM and the resulting organic phases were combined, dried, and concentrated under vacuum. The residue obtained was purified by chromatography on silica gel using DCM/IPrOH (9.5:0.5 to 8:2) as eluent to give $2 \mathbf{d}(19 \mathrm{mg}, 68 \%)$ as a white solid. $R_{\mathrm{f}}=0.3(\mathrm{DCM} /$ $\mathrm{MeOH}, 9: 1) .{ }^{1} \mathrm{H}$ NMR (500 MHz, $\left.\mathrm{CDCl}_{3} / \mathrm{CD}_{3} \mathrm{OD}\right): \delta_{\mathrm{H}}=8.84$, 7.50, 7.45, 6.54, $6.15(5 \times$ br., $5 \times 1 \mathrm{H}, 4 \mathrm{NH}, \mathrm{OH}), 7.39-7.32(\mathrm{~m}, 5$ $\mathrm{H}, H \mathrm{Ph}), 5.41(\mathrm{dd}, J=4.1, J=7.8 \mathrm{~Hz}, 1 \mathrm{H}, 6-\mathrm{H}), 5.23(\mathrm{~d}, J=$ $4.1 \mathrm{~Hz}, 1 \mathrm{H}, 5-\mathrm{H}), 5.22\left(\mathrm{~d}, J=3.6 \mathrm{~Hz}, 2 \mathrm{H}, \mathrm{CH}_{2} \mathrm{Ph}\right), 4.88[\mathrm{~m}, 1 \mathrm{H}$, $H \alpha($ Asn)], 4.52- 4.32 [m, 4 H, $H \alpha$ (Ala, Pro, Thr), $H \beta($ Thr)], 3.84 (s, $1 \mathrm{H}, 2-\mathrm{H}$ ), 3.64, $3.48\left[\mathrm{~m}, 2 \mathrm{H}, \mathrm{CH}_{2} \delta\right.$ (Pro)], $2.82[\mathrm{dd}, J=15.5, J$ $=6 \mathrm{~Hz}, 1 \mathrm{H}, \mathrm{C} H_{2 \mathrm{a}} \beta($ Asn $\left.)\right], 2.71[\mathrm{dd}, J=15.5, J=5.5 \mathrm{~Hz}, 1 \mathrm{H}$, $\mathrm{CH}_{2 \mathrm{~b}} \beta($ Asn $)$, 2.34-2.28 [m, $2 \mathrm{H}, \mathrm{CH}_{2} \beta$ (Pro)], 2.15-1.80 [m, $4 \mathrm{H}$, $\mathrm{CH}_{2} \gamma($ Pro $\left.), \mathrm{CH}_{2 \text { deca }}\right], 1.62$ (s, $\left.3 \mathrm{H}, \mathrm{CH}_{3}\right), 1.59$ (m, $2 \mathrm{H}, \mathrm{CH}_{2 \text { deca }}$ ), 1.48 (s, $3 \mathrm{H}, \mathrm{CH}_{3}$ ), 1.43 [d, $J=7.0 \mathrm{~Hz}, 3 \mathrm{H}, \mathrm{CH}_{3}$ (Ala)], 1.30-1.22 $\left(\mathrm{m}, 12 \mathrm{H}, 6 \mathrm{CH}_{2 \mathrm{deca}}\right), 1.16$ [d, $\left.J=6.0 \mathrm{~Hz}, 3 \mathrm{H}, \mathrm{CH}_{3}(\mathrm{Thr})\right], 0.87(\mathrm{t}$, $\left.J=7.0 \mathrm{~Hz}, 3 \mathrm{H}, \mathrm{C} H_{3 \text { deca }}\right) \mathrm{ppm} \cdot{ }^{13} \mathrm{C} \mathrm{NMR}\left(75 \mathrm{MHz}, \mathrm{CDCl}_{3} /\right.$ $\left.\mathrm{CD}_{3} \mathrm{OD}\right): \delta_{\mathrm{C}}=173.2,172.9,172.5,172.4,170.6,170.5,170.4,165.1$, $134.4,128.3,71.4,67.3,66.9,63.8,62.6,60.2,59.1,58.0,49.6,49.5$, $47.4,36.5,34.4,31.5,29.3,29.1,29.0,28.9,28.7,26.6,24.7,24.4$, 22.3, 19.0, 17.1, $13.7 \mathrm{ppm}$. HRMS (EI): calcd. for $\mathrm{C}_{41} \mathrm{H}_{61} \mathrm{~N}_{7} \mathrm{O}_{10} \mathrm{SNa}[\mathrm{M}+\mathrm{Na}]^{+}$866.4098; found 866.4109.

Supporting Information (see footnote on the first page of this article): Experimental characterization data $\left({ }^{1} \mathrm{H}\right.$ and ${ }^{13} \mathrm{C}$ NMR, HRMS) for all the compounds synthesized and procedures for the biological in vitro evaluation.

\section{Acknowledgments}

The authors are grateful for financial support from the Agentschap voor Innovatie door Wetenschap en Technologie (Rational Drug Design and Innovative High Throughput Screening Approach to Combat Antibiotic Resistant Bacteria, grant number 050146) and to Dr. J. Rozenski for performing the MS analysis

[1] M. Paetzel, A. Karla, N. C. Strynadka, R. E. Dalbey, Chem. Rev. 2002, 102, 4549-4580.

[2] K. M. Cregg, I. Wilding, M. T. Black, J. Bacteriol. 1996, 178, 5712-5718.

[3] T. Date, J. Bacteriol. 1983, 154, 76-83.

[4] M. Sung, R. E. Dalbey, J. Biol. Chem. 1992, 267, 13154-13159.

[5] G. von Heijne, Eur. J. Biochem. 1983, 133, 17-21.

[6] G. von Heijne, J. Mol. Biol. 1985, 184, 99-105.

[7] M. Paetzel, R. E. Dalbey, N. C. J. Strynadka, Nature 1998, 396, 186-190. 
[8] A. E. Allsop, G. Brooks, G. Bruton, S. Coulton, P. D. Edwards, I. K. Hatton, A. C. Kaura, S. D. Mclean, N. D. Pearson, T. C. Smale, R. Southgate, Bioorg. Med. Chem. Lett. 1995, 5, 443448.

[9] C. R. Perry, M. J. Ashby, S. A. Elsmere, Biochem. Soc. Trans. 1995, 23, 548S.

[10] J. Schimana, K. Gebhardt, A. Holtzel, D. G. Schmid, R. Sussmuth, J. Muller, R. Pukall, H. P. Fiedler, J. Antibiot. 2002, $55,565-570$.

[11] P. Kulanthaivel, A. J. Kreuzman, M. A. Strege, M. D. Belvo, T. A. Smitka, M. Clemens, J. R. Swartling, K. L. Minton, F. Zheng, E. L. Angleton, D. Mullen, L. N. Jungheim, V. J. Klimkowski, T. I. Nicas, R. C. Thompson, S. B. Peng, J. Biol. Chem. 2004, 279, 36250-36258.

[12] G. Bruton, A. Huxley, P. O’Hanlon, B. Orlek, D. Eggleston, J. Humphries, S. Readshaw, A. West, S. Ashman, M. Brown, K. Moore, A. Pope, K. O'Dwyer, L. Wang, Eur. J. Med. Chem. 2003, 38, 351-356.

[13] P. Buzder-Lantos, K. Bockstael, J. Anne, P. Herdewijn, Bioorg. Med. Chem. Lett. 2009, 19, 2880-2883.

[14] M. T. Black, G. Bruton, Curr. Pharm. Des. 1998, 4, 133-154.

[15] R. E. Babine, S. L. Bender, Chem. Rev. 1997, 97, 1359-1472.

[16] R. C. Thompson, Biochemistry 1973, 12, 47-51.

[17] B. Imperiali, R. H. Abeles, Biochemistry 1986, 25, 3760-3767.

[18] S. Venkatraman, S. L. Bogen, A. Arasappan, F. Bennett, K. Chen, E. Jao, Y. T. Liu, R. Lovey, S. Hendrata, Y. Huang, W. Pan, T. Parekh, P. Pinto, V. Popov, R. Pike, S. Ruan, B. Santhanam, B. Vibulbhan, W. Wu, W. Yang, J. Kong, X. Liang, J. Wong, R. Liu, N. Butkiewicz, R. Chase, A. Hart, S. Agrawal, P. Ingravallo, J. Pichardo, R. Kong, B. Baroudy, B. Malcolm, Z. Guo, A. Prongay, V. Madison, L. Broske, X. Cui, K. C. Cheng, Y. Hsieh, J. M. Brisson, D. Prelusky, W. Korfmacher, R. White, S. Bogdanowich-Knipp, A. Pavlovsky, P. Bradley, A. K. Saksena, A. Ganguly, J. Piwinski, V. Girijavallabhan, F. G. Njoroge, J. Med. Chem. 2006, 49, 6074-6086.

[19] J. B. Doherty, B. M. Ashe, L. W. Argenbright, P. L. Barker, R. J. Bonney, G. O. Chandler, M. E. Dahlgren, C. P. Dorn Jr., P. E. Finke, R. A. Firestone, D. Fletcher, W. K. Hagmann, R. Mumford, L. O'Grady, A. L. Maycock, J. M. Pisano, S. K. Shah, K. R. Thompson, M. Zimmerman, Nature 1986, 322, 192-194.

[20] J. C. Powers, J. L. Asgian, O. D. Ekici, K. E. James, Chem. Rev. 2002, 102, 4639-4750.

[21] C. A. Kettner, A. B. Shenvi, J. Biol. Chem. 1984, 259, 15106 15114.

[22] S. Venkatraman, W. Wu, A. Prongay, V. Girijavallabhan, G. F. Njoroge, Bioorg. Med. Chem. Lett. 2009, 19, 180-183.

[23] K. Achilles, M. Schneider, T. Schirmeister, H. H. Otto, Pharmazie 2000, 55, 798-802.

[24] N. E. Zhou, D. Guo, G. Thomas, A. V. Reddy, J. Kaleta, E. Purisima, R. Menard, R. G. Micetich, R. Singh, Bioorg. Med. Chem. Lett. 2003, 13, 139-141.
[25] P. Krogsgaard-Larsen, U. Madsen, K. Stromgaard, Textbook of Drug Design and Discovery, 4th ed., CRC Press, Boca Raton, FL, USA, 2009.

[26] D. A. Harris, M. E. Powers, F. E. Romesberg, Bioorg. Med. Chem. Lett. 2009, 19, 3787-3790.

[27] D. A. Case, T. E. Cheatham III, T. Darden, H. Gohlke, R. Luo, K. M. Merz Jr., A. Onufriev, C. Simmerling, B. Wang, R. J. Woods, J. Comput. Chem. 2005, 26, 1668-1688.

[28] J. Wang, R. M. Wolf, J. W. Caldwell, P. A. Kollman, D. A. Case, J. Comput. Chem. 2004, 25, 1157-1174.

[29] R. Moreira, A. B. Santana, J. Iley, J. Neres, K. T. Douglas, P. N. Horton, M. B. Hursthouse, J. Med. Chem. 2005, 48, 4861-4870.

[30] F. Broccolo, G. Cainelli, G. Caltabiano, C. E. Cocuzza, C. G. Fortuna, P. Galletti, D. Giacomini, G. Musumarra, R. Musumeci, A. Quintavalla, J. Med. Chem. 2006, 49, 2804-2811.

[31] S. Hanessian, D. Desilets, Y. L. Bennani, J. Org. Chem. 1990, 55, 3098-3103.

[32] G. Cainelli, M. Panunzio, T. Basile, A. Bongini, D. Giacomini, G. Martelli, J. Chem. Soc., Perkin Trans. 1 1987, 12, 2637-2642.

[33] C. Fuganti, S. Lanati, S. Servi, A. Tagliani, A. Bedeschi, G. Franceschi, J. Chem. Soc., Perkin Trans. 1 1993, 2247-2249.

[34] O. Mitsunobu, Synthesis 1981, 1-28.

[35] K. C. K. Swamy, N. N. B. Kumar, E. Balaraman, K. V. P. P. Kumar, Chem. Rev. 2009, 109, 2551-2651.

[36] T. Tsunoda, Y. Yamamiya, S. Ito, Tetrahedron Lett. 1993, 34, $1639-1642$.

[37] T. Tsunoda, Y. Yamamiya, Y. Kawamura, S. Ito, Tetrahedron Lett. 1995, 36, 2529-2530.

[38] R. Busson, H. Vanderhaeghe, J. Org. Chem. 1976, 41, 25612565.

[39] T. Fekner, J. E. Baldwin, R. M. Adlington, T. W. Jones, C. K. Prout, C. J. Schofield, Tetrahedron 2000, 56, 6053-6074.

[40] S. Kukolja, J. Am. Chem. Soc. 1971, 93, 6267-6269.

[41] S. Wolfe, W. S. Lee, Chem. Commun. (London) 1968, 242-245.

[42] J. W. Misner, J. W. Fisher, J. P. Gardner, S. W. Pedersen, K. L. Trinkle, B. G. Jackson, T. Y. Zhang, Tetrahedron Lett. 2003, 44, 5991-5993.

[43] J. Aszodi, A. Bonnet, G. Teutsch, Tetrahedron 1990, 46, 1579 1586.

[44] S. Kukolja, S. R. Lammert, J. Am. Chem. Soc. 1975, 97, 5582 5583.

[45] C. Helena, Š.-K. Marija, Arkivoc 2009, 7, 237-246.

[46] S. C. V. Rao, K. Bockstael, S. Nath, Y. Engelborghs, J. Anne, N. Geukens, FEBS J. 2009, 276, 3222-3234.

[47] P. Buzder-Lantos, K. Bockstael, J. Anne, P. Herdewijn, unpublished results.

[48] H. R. Josephine, P. Charlier, C. Davies, R. A. Nicholas, R. F. Pratt, Biochemistry 2006, 45, 15873-83.

Received: February 1, 2011

Published Online: 
及-Lactam Lipopeptide Synthesis

We present the design, asymmetric synthesis, and biological evaluation of novel $\beta$ lactam lipopeptides, inhibitors of the signal peptidase I, an essential bacterial enzyme for the viability of both Gram-negative and Gram-positive bacteria. The importance of the azetidinone moiety is demonstrated and can serve as a starting point to improve the structure of these new kinds of SPase I inhibitors.

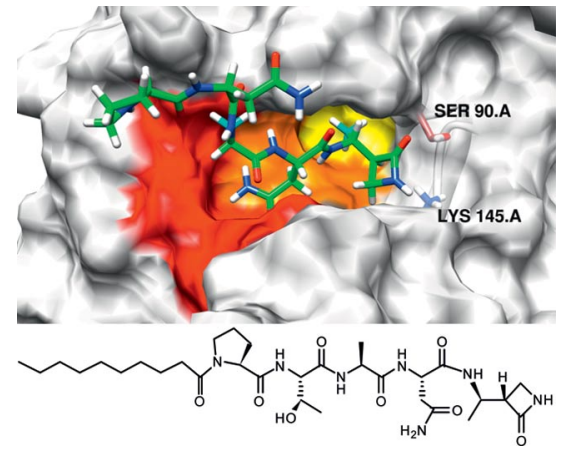

C. Crauste, M. Froeyen, J. Anné, P. Herdewijn* 1-14

Asymmetric Synthesis of New $\beta$-Lactam Lipopeptides as Bacterial Signal Peptidase I Inhibitors

Keywords: Medicinal chemistry / Antibiotics / Enzymes / Peptides / Lactams / Asymmetric synthesis 